Review

\title{
Long Non-Coding RNA (lncRNA) Roles in Cell Biology, Neurodevelopment and Neurological Disorders
}

\author{
Vincenza Aliperti ${ }^{1, *,+} \oplus$, Justyna Skonieczna ${ }^{2,+}$ and Andrea Cerase ${ }^{2, *}$ \\ 1 Department of Biology, University of Naples Federico II, 80126 Naples, Italy \\ 2 Centre for Genomics and Child Health, Blizard Institute, Barts and The London School of Medicine and Dentistry, \\ Queen Mary University of London, London E1 2AT, UK; j.b.skonieczna@smd19.qmul.ac.uk \\ * Correspondence: vincenza.aliperti@unina.it (V.A.); a.cerase@qmul.ac.uk (A.C.) \\ + These authors contributed equally to this work.
}

check for updates

Citation: Aliperti, V.; Skonieczna, J.; Cerase, A. Long Non-Coding RNA (lncRNA) Roles in Cell Biology, Neurodevelopment and Neurological Disorders. Non-coding RNA 2021, 7, 36. https://doi.org/10.3390/ncrna 7020036

Academic Editor: Michael Janitz

Received: 8 May 2021

Accepted: 15 June 2021

Published: 17 June 2021

Publisher's Note: MDPI stays neutral with regard to jurisdictional claims in published maps and institutional affiliations.

Copyright: (c) 2021 by the authors. Licensee MDPI, Basel, Switzerland. This article is an open access article distributed under the terms and conditions of the Creative Commons Attribution (CC BY) license (https:// creativecommons.org/licenses/by/ $4.0 /)$.

\begin{abstract}
Development is a complex process regulated both by genetic and epigenetic and environmental clues. Recently, long non-coding RNAs (lncRNAs) have emerged as key regulators of gene expression in several tissues including the brain. Altered expression of lncRNAs has been linked to several neurodegenerative, neurodevelopmental and mental disorders. The identification and characterization of lncRNAs that are deregulated or mutated in neurodevelopmental and mental health diseases are fundamental to understanding the complex transcriptional processes in brain function. Crucially, lncRNAs can be exploited as a novel target for treating neurological disorders. In our review, we first summarize the recent advances in our understanding of lncRNA functions in the context of cell biology and then discussing their association with selected neuronal development and neurological disorders.
\end{abstract}

Keywords: long non-coding RNAs; neurodevelopment; neurological disorders; neurodegeneration; neuropsychiatric disorders; Alzheimer's disease (AZ); amyotrophic lateral sclerosis (ALS); autism spectrum disorder (ASD); schizophrenia (SZ)

\section{Introduction}

For a long time, scientists believed that functional genetic information was only contained in protein-coding genes. Proteins were considered the main protagonists in cellular functions, while RNAs were thought to be mere intermediaries between DNA and proteins [1].

In recent years, advances in genomic sequencing technology and findings from largescale consortia have facilitated our understanding of the mammalian genome's complexity and flexibility. Indeed, genome-wide analyses of the eukaryotic transcriptome have shown that about $90 \%$ of the human genome is actually transcribed. Only about $2 \%$ of it is annotated as protein-coding genes (ENCODE Project Consortium, https: / / encodeproject.org, v117, accessed on 28 May 2021) [2], while the majority of transcripts represent non-coding RNAs (ncRNAs) [3]. ncRNAs are a heterogeneous group of genes that do not have functional open reading frames (ORFs) and are not transcribed into proteins. Due to these biological characteristics, for a long time, they were considered "junk" [4,5]. Recent data have shown that this part of the genome is functionally critical and is involved in physiological processes and tissue homeostasis [6,7] both in health and disease [8-18]. This has also been supported by the evolutionary analysis of conserved ncRNAs [8]. Indeed, while the number of protein-coding genes has remained relatively stable, the number of non-coding transcripts have increased considerably in parallel with the complexity of organisms [19]. In this review, we discuss the diverse, general mechanisms of action of well-studied lncRNAs and then focus on the role of lncRNAs in selected, primary examples of neurodevelopmental and neurological disorders. 


\subsection{Classification of $n c R N A s$}

NcRNAs may be grouped into different classes and classified according to size and function. In particular, ncRNAs are divided into two main classes: structural ncRNAs and regulatory ncRNAs (Figure 1) [20]. The former are usually considered constitutive and include ribosomal RNAs (rRNAs), transfer RNAs (tRNAs), small nuclear RNAs (snRNAs) and small nucleolar RNAs (snoRNAs). Regulatory ncRNAs, on the other hand, are in turn divided based on their length into three classes: short ncRNAs, which include microRNAs (miRNAs, 22-23 nucleotides (nts)) and piwiRNAs (piRNAs, 26-31 nts); medium ncRNAs (50-200 nts); and long ncRNAs (lncRNAs, > $200 \mathrm{nts}$ ) [21,22]. Most of these transcripts are generated by post-transcriptional cleavage. These can be small or large RNA fragments, which function independently from one another upon cleavage [23].

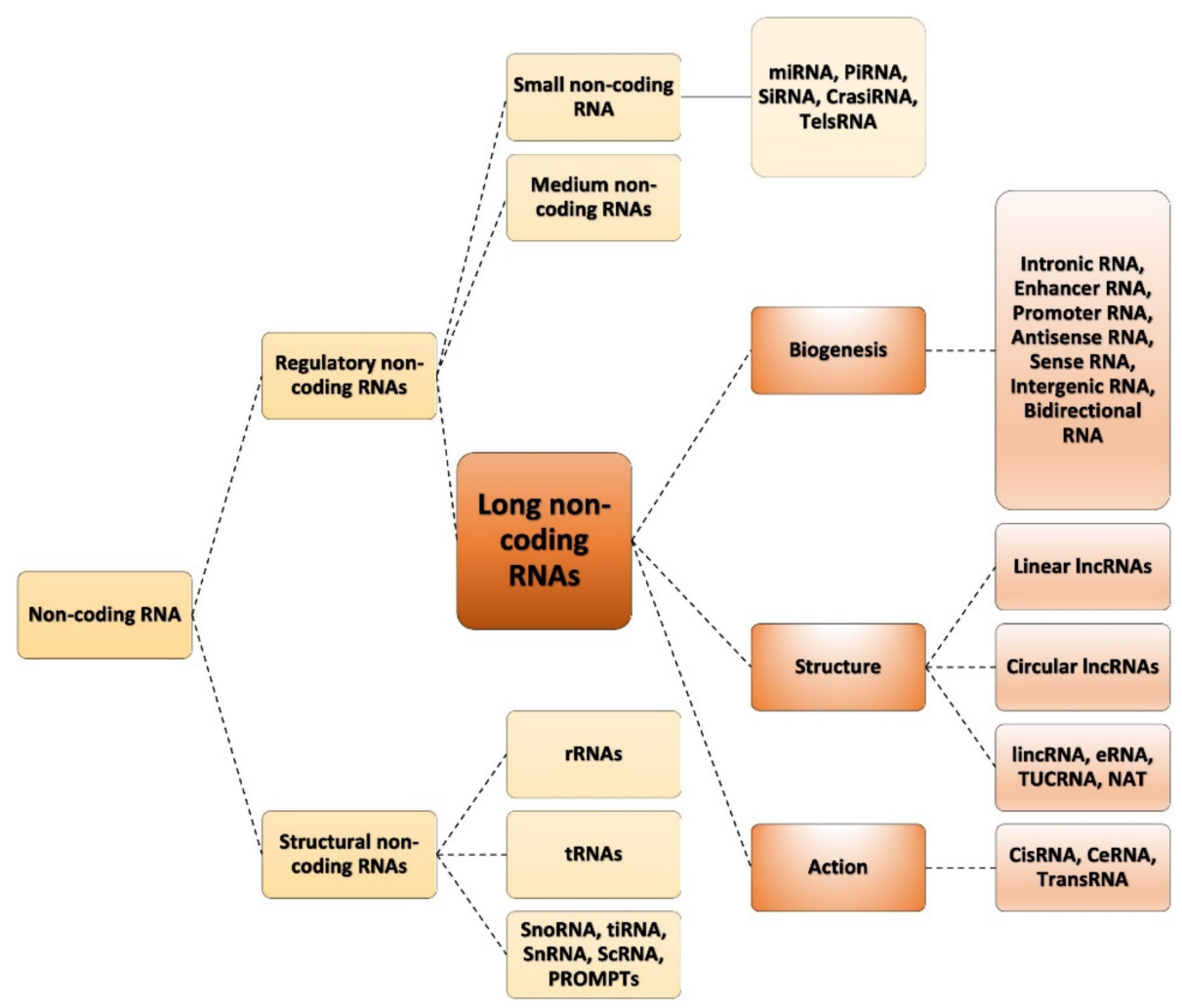

Figure 1. ncRNAs classes: schematic classification of ncRNAs into classes and sub-classes according to their actions, biogenesis and structures (snoRNA: small nucleolar RNAs; tiRNA: transcription initiation RNA; snRNA: small nuclear RNA; scRNA: small cytoplasmic RN; PROMPTs: promoter upstream transcripts; rRNAs: ribosomal RNAs; tRNAs: transfer RNAs; miRNA: micro RNA; piRNA: piwi RNA; siRNA: small interfering RNA; crasiRNA: centromere repeat-associated small interacting RNA; telsRNA: telomere-specific small RNA; lincRNA: long intergenic noncoding RNA; eRNA: enhancer-derived RNA; TUCRNA: transcribed ultraconserved RNA; NAT: natural antisense transcript; cis-lncRNA: cis-acting long non-coding RNA; ceRNA: competing endogenous RNA; trans-lncRNA: trans-acting long non-coding RNA).

\subsection{Biogenesis of $\operatorname{lncRNAs}$}

A significant part of non-coding transcripts is represented by lncRNAs, which are RNA transcripts longer than $200 \mathrm{nts}$. The biogenesis of lncRNAs resembles that of messenger RNAs (mRNAs). They are transcribed by polymerase II (Pol II) and can be polyadenylated, spliced and $5^{\prime}$-capped $[7,21,23]$. The mechanisms involved in the biogenesis of lncRNAs are cell type-specific and controlled by stage-specific stimuli [20]. They undergo posttranscriptional modifications and inter/intra-cellular transport. Most of them have different expression patterns and preferentially nuclear localization, in contrast to mRNAs, because 
they are involved in chromatin and epigenetic regulation of gene expression $[2,7,21,24]$. Once transcribed, lncRNAs fold into a thermodynamically stable secondary structure. RNA has the ability to form double helices, hairpins and pseudoknots thanks to high-level tertiary interactions, mainly mediated by couplings of non-canonical bases. As shown in Figure 2, four functional domains can be present in lncRNAs [25]:

A. RNA-binding domains. Thanks to their ability to base pair with other RNAs, lncRNAs can recognize and bind mRNAs, miRNAs and other lncRNAs, modulating target levels and function;

B. Protein-binding domains. Proteins are a major partner of lncRNAs, forming ribonucleoprotein complexes (RNPs) that act as chaperones, transport aids or effectors (including phase-separation seeding). This type of interaction involves conformational changes in the protein, RNA or both;

C. DNA-binding domains. Currently, there is a lack of extensive evidence for direct and functional interaction between lncRNAs and DNA as well as a lack of a consensus regarding the role and function of these interactions. However, it is known that RNA-DNA hybrids or triplex structures can allow single strands of RNA to interact with DNA duplexes through pair-base interactions. These direct interactions can efficiently and selectively direct RNA signals to genomic loci through base-pairing interactions. However, such interactions can also expose the genome to deamination and damage;

D. Conformational switch. LncRNAs can act as regulatory devices by allosterically coupling binding domains with the switching of structural conformations and thereby activating or suppressing linked functional domains.

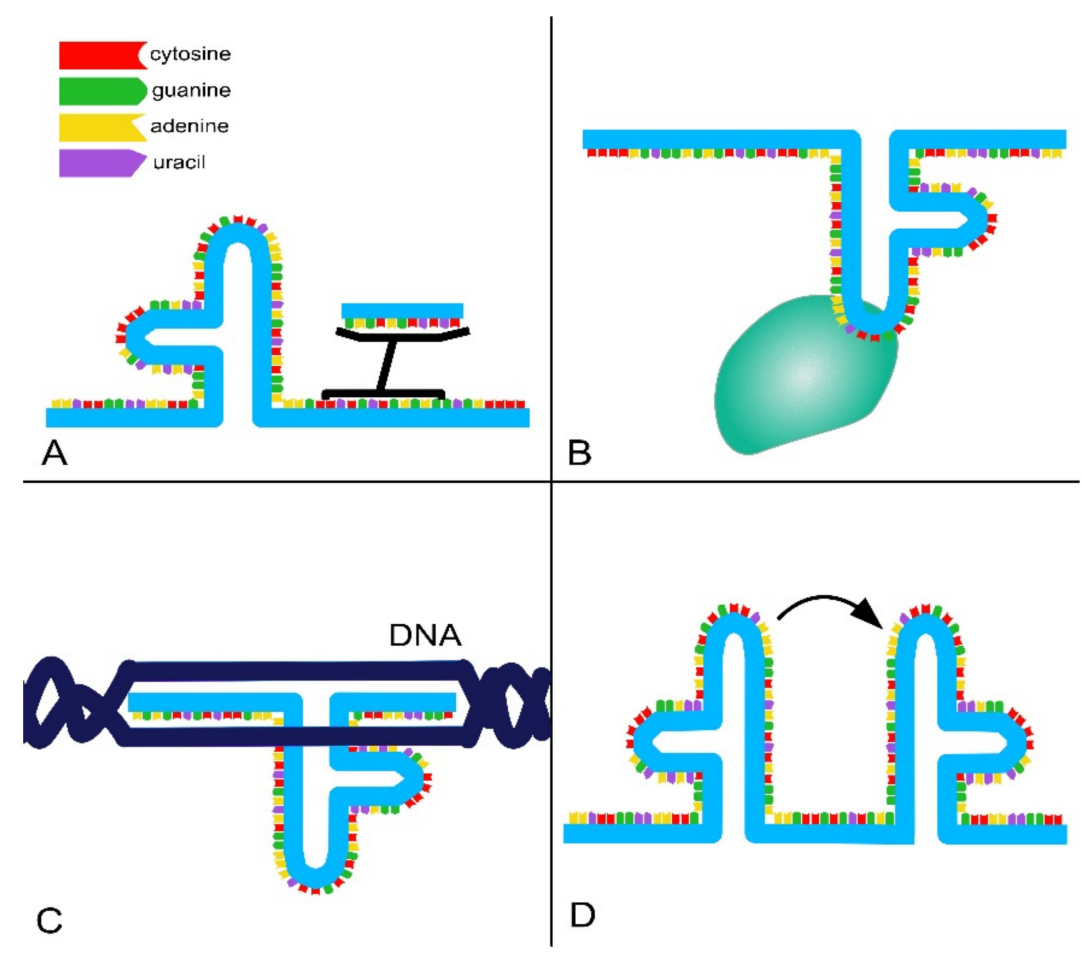

Figure 2. Domain architecture of lncRNAs. Schematic representation of lncRNAs' structural domains, through which they can bind other RNAs via complementary base-pair interactions (A), proteins (B) and DNA (C). These interactions can induce allosteric, conformational changes to other structures in the lncRNA (D).

\subsection{Types of $\ln R R N A s$}

LncRNAs can be classified based on their biogenesis, structure, localization or mechanism of action $[20,26,27]$. Based on their localization in the genome compared to proteincoding genes, they can be further divided into various subclasses (Figure 3) [28]: 
A. Sense lncRNAs, which overlap one or more exons of neighboring mRNAs on the same strand; antisense lncRNAs, which overlap one or more exons of neighboring mRNAs on the opposite strand; intronic lncRNAs, which are transcribed from introns of a second transcript (sometimes may represent pre-mRNA sequences);

B. Promoter upstream lncRNAs, which are located upstream of a promoter; promoterassociated lncRNAs, which are close to the promoter;

C. Intergenic lncRNAs, which lie within the genomic interval between two genes;

D. Bidirectional lncRNAs, which have promoters in common with protein-encoding genes but are transcribed in the opposite direction; $3^{\prime}$ UTR-associated lncRNAs, which are transcribed from a protein-coding gene's $3^{\prime} \mathrm{UTR}$ region.

A

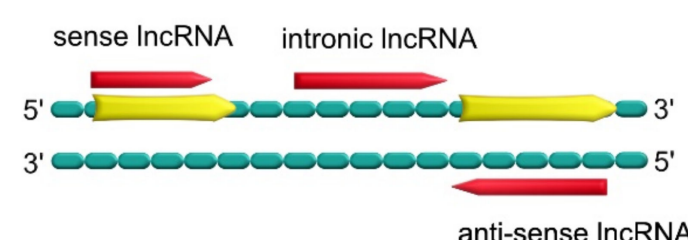

C

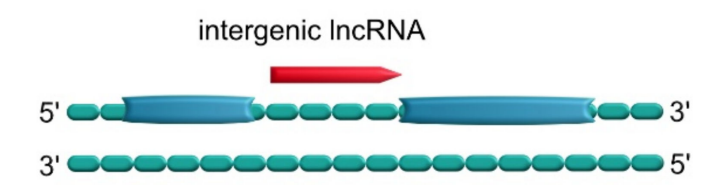

B

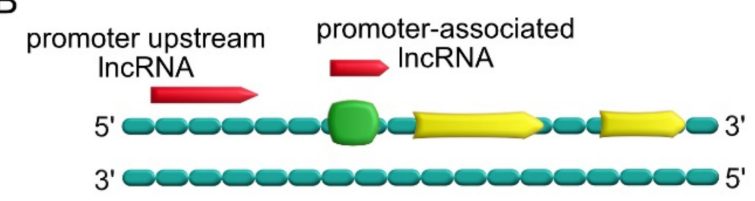

D

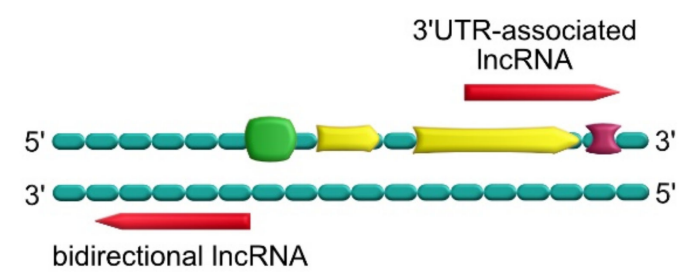

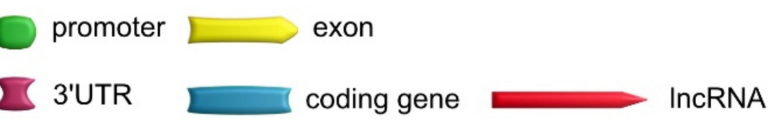

Figure 3. Classification of lncRNAs. (A) Sense lncRNAs and antisense lncRNAs are, respectively, present on the same and opposite strands and overlap with neighboring mRNAs; intronic lncRNAs are transcribed from the introns of the protein-coding genes. (B) Promoter upstream lncRNAs are located upstream of the promoter; promoter-associated lncRNAs are close to the promoter. (C) Intergenic lncRNAs are transcribed from the genomic interval between two genes. (D) Bidirectional lncRNAs have transcription start sites that are close to adjacent genes on the antisense strand, and these have common promoters; 3'UTR-associated lncRNAs are obtained from a protein-coding gene's 3'UTR region.

Another approach in the classification of lncRNAs is based on their subcellular localization, which can be linked to their function (such as chromatin-associated lncRNAs, chromatin-interlinking RNAs, nuclear bodies-associated RNAs and PRC2-associated RNAs [29]) or to their structure, distinguishing linear lncRNAs from the circular lncRNAs (circRNAs that are produced in a process called "back-splicing" [30].

Finally, based on the mode of action, IncRNAs can be divided into cis-acting lncRNAs, trans-acting lncRNAs (i.e., working on the same chromosome they are transcribed for, or not, respectively) and competing endogenous lncRNAs, which share sequence and function similarities with mRNAs and compete with them for function [20,29].

\subsection{Evolution, Conservation and Stability of $\operatorname{lnc} R N A s$}

Comparing lncRNAs with protein-coding genes and small ncRNAs, lncRNAs were found to be poorly conserved at the primary structure level (i.e., sequence conservation). In fact, for protein-coding genes, the average number of nucleotide substitutions is approximately $10 \%$, while for lncRNAs, this number increases up to $90-95 \%$, thus estimating that only $5-10 \%$ of the sequences are preserved [31]. A noticeable example is Xist, the lncRNA involved in the inactivation of one of the two X chromosomes in mammalian females, which appears to be relatively poorly conserved in some eutherians' clades [32]. 
Multidisciplinary studies have, however, highlighted how regions such as the promoter and the exon-intron boundaries are much more conserved in lncRNAs sequence [33]. Furthermore, in a recent work, Kirk and colleagues [34] developed the SEEKR (sequence evaluation through k-mer representation) method, which allows quantifying the similarity of nonlinear sequences between IncRNAs by evaluating all possible sequence combinations at a given length $(\mathrm{k})$ within the lncRNA. In this way, it is possible to expand the number of significant correlations with protein binding and lncRNA subcellular localization. For example, substantial levels of nonlinear sequence similarity were found between functional domains in Xist and domains in the Rs $x$ lncRNA, a marsupial lncRNA originating from convergent evolution that has been proposed as a functional analogue of Xist $[35,36]$. Therefore, $\mathrm{k}$-mer represents a promising approach for the functional classification of lncRNAs based on their sequence [36].

Sequence analysis and experimental investigation also allowed obtaining information on the lncRNAs' secondary structure. LncRNA secondary structures are characterized by modular structures, organized in independent RNA modules with different functions. Each domain contains several structural motifs such as internal and terminal loops as well as helices and junction regions regulating its function. [37]. To date, few lncRNAs have been characterized at the secondary structure level including Xist [37-41], HOTAIR [37,42], lincRNA- $p 21[37,43]$ and several others. For instance, HOTAIR consists of four independent domains containing 56 helical segments, 38 terminal loops, 34 internal loops and 19 junction regions [37,42]; Xist is characterized by different conserved regions of tandem repeats, which are indispensable for specific functions [44]. For example, its $5^{\prime}$ region is highly conserved and consists of 8.5 copies in humans ( 7.5 in mice) of 26 -mers separated by U-rich linkers (A-repeat) that assume double stem-loop structure ensembles, which function as a platform for the protein binding involved in gene silencing [44]. All these structures can undergo rearrangements due to polymorphisms or post-transcriptional modifications that alter their stability. It is therefore deduced that lncRNAs do not strictly have a conserved primary structure but maintain conserved functions that are carried out through the promoter regions, splicing patterns, expression patterns and secondary structure through interaction with RNA-binding proteins [26,45].

Stability is an important feature for the functional analysis of lncRNAs. It is, in fact, known that the average half-life of each RNA is related to its physiological function. LncRNAs have a much shorter half-life and greater variability than mRNAs. In particular, it is possible to divide lncRNAs into unstable (average half-life $<2 \mathrm{~h}$ ), stable (average half-life $>2 \mathrm{~h}$ ) and extremely stable (average half-life $>16 \mathrm{~h}$ ). Furthermore, intergenic and antisense lncRNAs are more stable than intronic ones, just as the transcripts that have undergone splicing are more stable than those that have not undergone it (single exon). Finally, nuclear lncRNAs are probably more unstable than others with different subcellular locations [46].

\section{Functional Roles of lncRNA in Cellular Processes}

LncRNAs are dynamically expressed during cell differentiation and development. They are able to regulate the cell cycle, genetic imprinting and stem cell reprogramming [26,45-51]. An increasing number of lncRNAs are specifically expressed during brain development as well as neural stem cell and progenitor differentiation. Some examples are MALAT1 (metastasis-associated lung adenocarcinoma transcript 1 ), which regulates synaptogenesis, and Sox2OT (Sox2 overlapping transcript), which overlaps the Sox2 gene encoding for a transcription factor important for neural stem cell self-renewal [52]. LncRNAs play a key role in the development and onset of several related neuropathologies such as Down syndrome, Rett syndrome, Fragile $\mathrm{X}$ syndrome and autism spectrum disorders, wherein abnormal expression of lncRNAs affects neurodevelopment and plays a major role in pathogenesis [3,52-57].

The main biological functions of lncRNAs include epigenetic regulation, chromatin remodeling and protein metabolism control. They can act at the transcriptional and post- 
transcriptional level, in cis or trans, and also act as a signaling molecule with a scaffolding role $[20,28,50]$. By definition, lncRNAs are different from coding mRNAs because they lack a substantial ORF and fail to produce proteins [26,58-60]. However, recent evidence has shown that some annotated lncRNAs can actually encode small functional peptides [61]. In addition, a recent analysis by Ruiz-Orera and colleagues [62] on ribosome profiling experiments provided important evidence that lncRNAs associated with ribosomes might play an important role in de novo protein evolution by encoding short peptides. The role of these peptides is not yet known and if they are functional. It is therefore believed that exploring the pathological and physiological effects of the new peptides generated by lncRNAs can unlock new fields of investigation.

\subsection{Mechanisms of Action}

LncRNAs are very versatile molecules that have the ability to create physical and functional interactions with DNA, RNA and proteins through base pairing or through functional domains, which are generated thanks to their secondary and tertiary folding (discussed above) [63].

LncRNAs can regulate gene expression positively or negatively through multiple mechanisms. Many lncRNAs act via chromatin modulation by working as molecular scaffolds for protein-protein interactions or interacting with chromatin-modifying complexes and recruiting chromatin-modifying complexes at specific loci to activate or repress target gene expression $[64,65]$. Some lncRNAs affect transcription by modulating the binding of the general transcription machinery and regulatory factors [4,29,65-67]. They are involved in RNA processing $[65,68]$, RNA turnover, silencing, translation and decay of mRNAs $[49,65,69,70]$ or act as miRNA sponges to neutralize miRNA-mediated mRNA silencing [65,71]. In addition, some lncRNAs are determined to be precursors of certain miRNAs at particular stages of development [30,65].

The function of lncRNAs also depends on their subcellular localization. They can localize in different cellular compartments including the nucleus, the chromatin and the cytoplasm based on sequence and structural motifs [72]. For example, the AGCCC motif is strongly correlated with lncRNAs nuclear localization [73]. Therefore, more and more resources have been spent on the design of tools that allow predicting lncRNAs sub-cellular location using nucleotide compositions [72,74]. Many are important modulators for nuclear functions. Several lncRNAs act in cis on their transcription sites. In this way, they manage to modulate local gene expression, both by recruiting transcription factors and/or chromatin modifiers and might be forming a DNA-RNA triplex that anchors lncRNA and the effector proteins associated with the gene promoter [20]. Others need to be relocated from their synthesis sites while maintaining nuclear localization. They, therefore, act in trans to have an impact on gene regulation. Finally, other lncRNAs must be exported to the cytoplasm to play their regulatory roles, interfering with post-translational modifications or influencing gene regulation by acting as decoys for miRNAs and proteins $[20,28,50]$.

\subsection{LncRNAs as Chromatin Regulators}

LncRNAs are involved in global epigenetic reprogramming during cell growth and development. Within the nucleus, they can affect chromatin status through inter- and intrachromosome interactions, remodeling chromatin and its condensation by acting on specific chromatin loci and regulating gene expression through mechanisms such as methylation or acetylation without changing the DNA sequence. Additionally, lncRNAs influence chromosome bridging by binding to heterogeneous nuclear ribonucleoprotein $U[3,5,28,64]$. A fraction of lncRNAs bind to the Polycomb repressive complex 1/2 (PRC1/2) [75] or the chromatin-modifying proteins CoREST and SMCX [76]; others bind to trithorax chromatinactivating complexes (trxG) [77]. These complexes act as antagonists in gene expression regulation during cell development and differentiation. In particular, while the PRC2 complex plays a role in repressive histone modifications, trxG promotes the transcriptional activation of Hox genes [78,79]. 
The well-characterized lncRNAs HOTAIR, ANRIL, XIST and KCNQ1OT1 are able to recruit epigenetic modifiers to specific loci for reprogramming the chromatin state $[64,80]$. For example, HOTAIR acts as a scaffold for coordinating the targeting of specific repressive, histone-modifying complexes to target loci [80]; XIST mediates X chromosome inactivation by recruiting repressive histone complexes such as PRC1 and PRC2 [81-83] and DNAmethylating complex [84]. Additionally, lncRNAs affect allelic gene expression through imprinting. Gene expression is regulated by specific genomic loci where protein-coding genes and lncRNAs are reciprocally expressed (Nesp/Nespas, Igf2r/Air, Dlk1/Gtl2). Moreover, some lncRNAs in specific loci may also control the imprinting regulation of neighboring genes via additional epigenetic factors [7].

\subsection{Transcriptional, Post-Transcriptional and Post-Translational Regulation}

The regulation of transcription by lncRNAs is mediated through chromatin regulation and various transcription factors (TFs), modifying lncRNAs activity and/or binding [28,49,64] In particular, some lncRNAs regulate transcription via competing for TFs or recruiting TFs acting as either co-activators or co-repressors of specific genes [7,28,49,85-88]; others lncRNAs directly act on RNA polymerase II by interacting with the initiation complex $[89,90]$.

LncRNAs play a key role also in post-transcriptional events such as mRNA splicing, editing, transport, translation and degradation $[28,30,64]$. For instance, several nuclear lncRNAs including NEAT1, MALAT1, MIAT (also known as GOMAFU) and SAF were linked to splicing regulation. They recognized splicing factors and influenced their activity by either modulating their post-translational modifications (e.g., phosphorylation) or by regulating interactions with other splicing factors and with protein-coding mRNAs [19,91-94]. Furthermore, lncRNAs can be implicated in alternative splicing through lncRNA-mediated chromatin remodeling [92,93]. For example, MIAT binds splicing factor 1 (SF1) protein through its UACUAAC repeat sequences and inhibits splicing and spliceosomal complex formation [95]; MALAT1 regulates the alternative splicing of endogenous target genes through the modulation of the phosphorylation status of splicing factors [68,96].

LncRNAs can also regulate RNA levels. Some of them can alter their stability by acting on the $3^{\prime}$ UTR regions rich in AU elements, with consequences for transcript degradation, decapping and deacetylation [7,49,69]; others such as BACE1AS can act to form an RNA-RNA duplex, increasing the stability of the mRNA [7,49,97].

LncRNAs can also act as scaffolds for higher-order complexes. For examples, lncRNAs can organize translational particles during ribosome translation in the endoplasmic reticulum (ER) [36] and to mediate stress granule formation through RNA-RNA interactions [5]. Finally, they can interact synergistically with mRNAs and act as miRNA inhibitory regulators modulating target expression $[28,30,64,98-100]$.

Finally, lncRNAs play a role in the post-translational modifications of proteins including phosphorylation, ubiquitination and acetylation. Therefore, they regulate protein formation, degradation and expression [101]. For example, in cancer, the lncRNAs HULC promotes cell proliferation through activation of the ERK pathway, with consequent phosphorylation of YB-1 preventing its interaction with other oncogenic mRNAs [102].

\section{LncRNAs in Neurological and Neurodegenerative Disorders}

LncRNAs are involved in the cell differentiation and function of all cell lineages. Given the many functions of lncRNAs, it is important to understand that any mutation resulting in either gain- or loss-of-function can have a major impact on protein synthesis, metabolism and many other cellular activities. In this review, we will focus on selected examples of neurological and neurodevelopmental disorders (see below).

Several pieces of evidence have shown that lncRNAs dysregulation is related to various neurological disorders including neurodegenerative diseases and neuropsychiatric disorders $[50,65]$. Neurodegenerative disorders are characterized by progressive neuron dysfunction and/or degeneration, affecting the nervous system functionality. The consequent clinical symptoms, both motor and cognitive, vary and are characteristic of the 
specific disorder. Moreover, neurodegenerative disorders can be age-related or non-agerelated and sex-biased and be either familiar or sporadic [4,26,31,103,104]. LncRNAs play a significant role in the pathophysiology of these disorders due to their important regulatory functions within the cell, involvement in various signalling pathways and the functioning of mitochondria; hence, their dysregulation may lead to the death of neurons and brain atrophy (Table 1) $[26,105,106]$. Therefore, it is crucial to expand our knowledge on the lncRNAs involved in the pathophysiology of these diseases and their mechanisms of action. In this way, we will be able to gain a better understanding of the processes underlying neurological diseases (for example, the signaling pathways involved) in order to create better diagnostic tools and new forms of treatments [106].

Table 1. LncRNAs dysregulated in neurodegenerative disorders. The chosen examples of lncRNAs involved in neurodegenerative disorders. (UP: upregulation; DOWN: downregulation; references are also shown).

\begin{tabular}{|c|c|c|c|c|}
\hline LncRNA & $\begin{array}{l}\text { Expression } \\
\text { Change }\end{array}$ & Role & $\begin{array}{l}\text { Linked } \\
\text { Disorder }\end{array}$ & References \\
\hline$B A C E 1-A S$ & UP & $\begin{array}{l}B A C E 1-A S \text { enhances mRNA BACE1 stability } \\
\text { and activity. Leads to } A \beta \text { formation through } \\
\text { the amyloid pathway. }\end{array}$ & $\mathrm{AD}$ & $\begin{array}{l}\text { Faghihi et al., } 2008 \text { [97]; } \\
\text { Faghihi et al., } 2010 \text { [71] }\end{array}$ \\
\hline $51 A$ & UP & $\begin{array}{l}51 A \text { upregulates SORL1 variant } A \text {, which } \\
\text { leads to } A \beta \text { accumulation through altered } \\
\text { amyloid processing. }\end{array}$ & $\mathrm{AD}$ & $\begin{array}{l}\text { Ma et al., } 2009 \text { [107]; } \\
\text { Ciarlo et al., } 2013 \text { [108]; } \\
\text { Luo and Chen } 2016 \text { [109] }\end{array}$ \\
\hline $17 A$ & UP & $\begin{array}{l}17 A \text { disrupts GABAergic signalling (through } \\
\text { the inhibition of GABAB R2 activity). This } \\
\text { leads to an inflammation response and } \\
\text { upregulation of } A \beta \text { formation and increases } \\
\text { the } A \beta x-42 / A \beta x-40 \text { ratio. }\end{array}$ & $\mathrm{AD}$ & $\begin{array}{l}\text { Massone et al., } 2011 \text { [110]; } \\
\text { Gavazzo et al., } 2013 \text { [111]; } \\
\text { Buggia-Prevot and Thinakaran, } 2014 \text { [112] }\end{array}$ \\
\hline NDM29 & UP & $\begin{array}{l}\text { NDM } 29 \text { promotes the cleavage activity of } \\
\gamma \text {-secretase and } B A C E 1 \text { secretase, increasing the } \\
\text { production of } A \beta \text { formation and the } A \beta x-42 / \\
A \beta x-40 \text { ratio. Moreover, it triggers an } \\
\text { inflammatory response. }\end{array}$ & $\mathrm{AD}$ & Massone et al., 2012 [113] \\
\hline BC200 & UP & $\begin{array}{l}B C 200 \text { takes part in the maintenance of } \\
\text { long-term synaptic plasticity by targeting } \\
\text { eIF4A and interacting with local proteins. In } \\
\text { AD, it leads to the increased loss of synapses. }\end{array}$ & $\mathrm{AD}$ & $\begin{array}{l}\text { Mus et al., } 2007 \text { [114]; } \\
\text { Lin et al., } 2008 \text { [115] }\end{array}$ \\
\hline NAT-Rad18 & UP & $\begin{array}{l}\text { NAT-Rad18 increases the cell death rate in } \\
\text { neurons, promoting the apoptotic processes. }\end{array}$ & $\mathrm{AD}$ & $\begin{array}{l}\text { Iacoangeli et al., } 2010 \text { [116]; } \\
\text { Massone et al., } 2012 \text { [113]; } \\
\text { Luo and Chen, } 2016 \text { [109] }\end{array}$ \\
\hline \multirow{2}{*}{ NEAT1 } & UP/DOWN & $\begin{array}{l}\text { NEAT1 is involved in the decreased } \\
\text { clearance of } A \beta .\end{array}$ & $\mathrm{AD}$ & $\begin{array}{l}\text { Wang et al., } 2019 \text { [117]; } \\
\text { Zhao et al., } 2019 \text { [118]; }\end{array}$ \\
\hline & UP & $\begin{array}{l}\text { NEAT1 regulates the assembly of paraspeckles } \\
\text { and might trigger neurotoxic processes in ALS. }\end{array}$ & ALS & $\begin{array}{l}\text { Clemson et al., } 2009 \text { [119]; } \\
\text { Suzuki et al., } 2019 \text { [120] }\end{array}$ \\
\hline MALAT1 & UP & $\begin{array}{l}\text { MALAT1 facilitates paraspeckle formation by } \\
\text { binding with FUS and TDP-43. Moreover, it } \\
\text { controls the phosphorylation of SR proteins } \\
\text { and gene expression in cis. }\end{array}$ & ALS & $\begin{array}{l}\text { Clark et al., } 2014[50] ; \\
\text { An et al., 2019 [121]; } \\
\text { Wu and Kuo, } 2020[106]\end{array}$ \\
\hline C9ORF72 & UP & $\begin{array}{l}\text { C9ORF72 extended repeats mutation leads to } \\
\text { the repeat-associated translation into neurotoxic } \\
\text { misfolded proteins and dipeptides. Contributes } \\
\text { to the SGs' formation and cellular inclusions. }\end{array}$ & ALS & $\begin{array}{l}\text { Mizielinska et al., } 2014 \text { [122]; } \\
\text { Wen et al., } 2014 \text { [123]; } \\
\text { Maharjan et al., 2017 [124]; } \\
\text { Wan et al., 2017 [29]; } \\
\text { Swinnen et al., 2018 [125] } \\
\text { Bampton et al., 2020 [126] } \\
\text { Mizielinska et al., } 2013 \text { [127] }\end{array}$ \\
\hline SATIII $(H s r \omega)$ & UP & $\begin{array}{l}\text { SAT III binds to TDP- } 43 \text { and takes part in } \\
\text { promoting its elongation (by binding to the } \\
\text { ELL2 domain) during the transcription, which } \\
\text { can affect TDP- } 43 \text { neurotoxicity. }\end{array}$ & ALS & $\begin{array}{l}\text { Chung et al., } 2018 \text { [128]; } \\
\text { Chen, K. and Chen, } 2020 \text { [5]; } \\
\text { Wu, et al., } 2020 \text { [106] }\end{array}$ \\
\hline$A T X N 2-A S$ & DOWN & $\begin{array}{l}\text { ATXN1-AS extended repeats form RNA foci } \\
\text { and lead to an increase in apoptosis through } \\
\text { interactions with caspase } 3 / 7 \text {. }\end{array}$ & ALS & Li et al., 2016 [129] \\
\hline SNAP25-AS & DOWN & $\begin{array}{l}\text { SNAP25AS affects SNAP } 25 \text { and processes } \\
\text { controlled by it such as synaptic vesicle } \\
\text { transport or axonal repair processes. }\end{array}$ & ALS & $\begin{array}{l}\text { Gagliardi et al., } 2018 \text { [130]; } \\
\text { Wu et al., } 2020 \text { [106] }\end{array}$ \\
\hline
\end{tabular}


For this review, we selected noticeable examples of lncRNA role in diseases such as Alzheimer's disease (AD) and amyotrophic lateral sclerosis (ALS). Finally, as prime examples of defective neurodevelopment, we chose to discuss the role of lncRNA in schizophrenia (SZ) and autism (ASD).

\subsection{Alzheimer's Disease}

$\mathrm{AD}$ is one of the most prevalent aging-related neurodegenerative diseases and causes of dementia worldwide $[109,131,132]$. This disease is characterized by progressive degeneration of cortical neurons, leading to brain tissue atrophy and clinical symptoms such as dementia and cognitive decline. The two main characteristics of AD are the accumulation of amyloid-beta $(\mathrm{A} \beta)$ in the extracellular senile plaques and hyperphosphorylated tau protein in the intracellular neurofibrillary tangles [26,106,131-134]. However, several other factors can cause neurodegeneration such as neuroinflammation and oxidative stress [131].

$\mathrm{AD}$ is a multifactorial disease associated with several risk factors. It has a strong genetic component, with mutations in genes responsible for $A \beta$ processing linked to the pathophysiology of this disease. Research from recent years has shown that lncRNAs play a major role in AD through epigenetic control of target genes (Table 1) [135-138]. Studies evaluating the profiles of aberrantly expressed transcripts in AD animal models showed that most of the lncRNAs upregulated or downregulated in AD were linked to metabolic pathways (in some cases, through insulin signalling), inflammatory processes and also synaptic transmission $[136,139]$. Interestingly, some lncRNAs that are dysregulated in $\mathrm{AD}$ have an opposite expression profile in cancer. For instance, the transcripts linked to neurodegeneration that are downregulated in AD are instead upregulated in cancer and involved in processes associated with the survival and proliferation of cancer cells [136,140].

One of the best-studied lncRNAs transcripts to date is BACE1-AS (Table 1), which is the antisense transcript to the gene encoding beta-secretase 1 (BACE1), which is involved in the amyloid pathway of $A \beta$ cleavage. In particular, the enzyme encoded by $B A C E 1$ is responsible for the cleavage of the amyloid precursor protein (APP). BACE1 overexpression results in the increased synthesis of the misfolded protein. Therefore, BACE1 levels can be used as a blood plasma biomarker for brain amyloidosis in people with AD $[137,141]$. BACE1-AS expression upregulates the transcription of BACE1 mRNA through the formation of stabilizing RNA duplex by binding to the open reading frame of BACE1 and masking the miRNA-485-5p binding site [71,97]. This event can trigger an increase of both $B A C E 1$ mRNA and protein levels, leading to enhanced $A \beta$ formation (Figure 4) [118,142-144]. Finally, BACE1-AS can decrease the level of miR-132-3p, which plays an important role in synaptic plasticity and activation [106,143].

BC200 (brain cytoplasmic 200 RNA) (Table 1) is responsible for the synthesis of dendritic neural proteins and for long-term synaptic plasticity regulation by targeting eukaryotic initiation factor 4A (eIF4A). In AD, this transcript becomes upregulated with aging and disease progression with consequent alteration to the regulation of synaptic and dendritic transport through the microtubules, which leads to their degeneration $[26,106,109,113,114,145]$.

Another interesting example of lncRNA linked to AD pathophysiology is the product of the sortilin receptor $1^{\prime}$ s (SORL1) first intron, regulated byalternative splicing (51A) (Table 1). It has been reported that in AD patients, $51 A$ is upregulated, along with the lower level of SORL1 expression. 51A regulates the alternative splicing of SORL1 mRNA, downregulating the production of the canonical variant of this receptor. These events can drive AD pathophysiology, as SORL1 has a neuroprotective property by binding to apolipoprotein $\mathrm{E}$ (APOE), which interacts with $\mathrm{A} \beta$, reducing APP oligomerization in the BACE1 amyloid pathway [109,142,146-148].

LncRNA E230001N04Rik has been shown to regulate tau aggregates production in AD in the okadaic-acid induced in vitro AD model. This happens due to the upregulation of E230001N04Rik lncRNA's neighboring genes, which are responsible for tau's production (Sepk1), stability and aggregation (Fkbp5). Both of these genes are upregulated in AD 
patients. Moreover, the KD of this lncRNA in the HT22 cell line resulted in significantly lower tau production compared to the control [136].

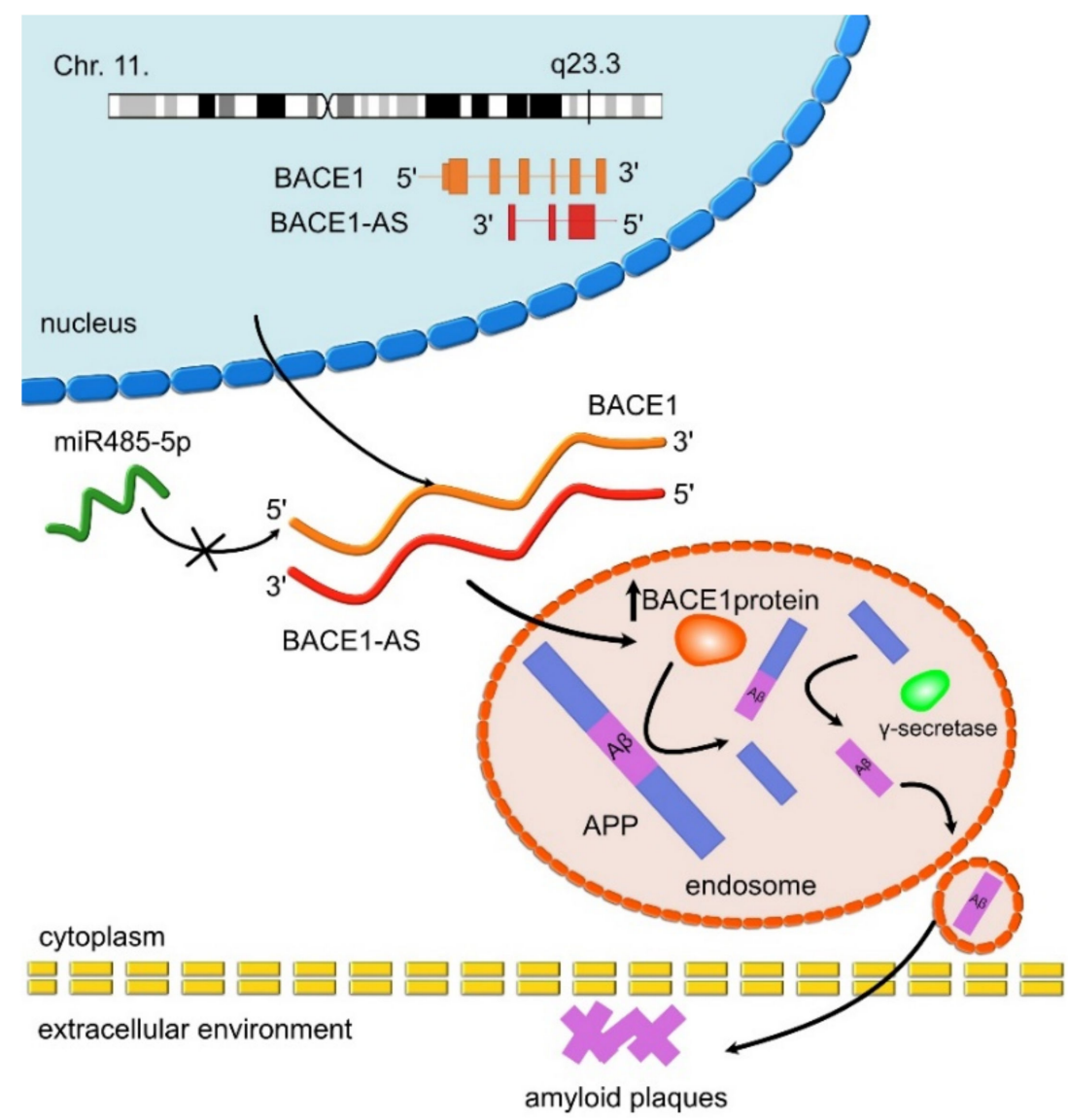

Figure 4. BACE1-AS involvement in AD pathophysiology. The BACE1-AS locus is localized on chromosome 11 (www.genecards.org, accessed on 28 April 2021). Its product binds to BACE1, stabilizing this mRNA and masking a binding place for miR485-5p, which normally inhibits the $B A C E 1$ enzyme translation. In this way, BACE1 leads APP into the amyloid pathway, increasing the production of the $A \beta$ aggregates into the amyloid plaques.

LncRNAs BDNF-AS and GDNF-OS are, respectively, the antisense transcripts of brainderived neurotrophic factor (BDNF) and glial cell line-derived neurotrophic factor (GDNF). They both negatively regulate neurotrophic factor expression, promoting the pathogenesis of AD. In fact, low levels of BDNF and GDNF cause a minor neuroprotective effect against $A \beta$ accumulation $[29,149,150]$.

\subsection{Amyotrophic Lateral Sclerosis (ALS)}

ALS, also known as motor neuron disease (MND), is a severe neurodegenerative disorder that is not related to natural aging [151-154]. The progressive degeneration of neurons in ALS is observed in both upper and lower motor neurons. Depending on the affected region of the nervous system, ALS can result in various clinical symptoms, inevitably leading to muscle paralysis. The exact etiology is still unknown, and its pathophysiology can be quite diverse and involves mitochondrial dysfunction, the defective metabolism of RNA, disrupted axonal transport and misfolded protein aggregation $[29,106,153,154]$. As ALS has such diverse pathophysiology, there are still a lot of unknown mechanisms that may be driving its pathophysiology. LncRNAs have already been shown to play an important role in many of these mechanisms, especially in intracellular inclusion formation, which is a hallmark of ALS (Table 1) [106,155]. Some of these inclusions are stress granules (SGs) located in the endoplasmic reticulum; others are nuclear bodies (NBs) within the 
nucleus $[49,156]$. All of them are membranelle structures composed of RNAs and proteins, the formation of which takes place through liquid-liquid phase separation (LLPS) and is controlled by lncRNAs and RNA-binding proteins $[156,157]$. LLPS in healthy conditions is a reversible process wherein RNA low complexity domains, proteins and heterogeneous nuclear ribonucleoproteins interact and bind, forming droplet-like structures within the environment with liquid-like properties [126]. These structures are involved in homeostasis, but in ALS, due to increased cellular stress, they do not dissolve and lead to neurotoxicity. One of the key lncRNAs involved in their formation through LLPS is NEAT1 (nuclear enriched abundant transcript 1) (Table 1), which regulates both SGs' and NBs' assembly and dynamics (Figure 5) $[119,121,156,158,159]$. NEAT1 is most predominantly present in two forms: NEAT1_1, which regulates transcription by chromatin activation and NEAT1_2, which regulates the formation of paraspeckles (nuclear RNA granules formed through liquid-liquid phase separation). This second form is linked to ALS susceptibility [20,121]. In fact, in healthy mammals, generally NEAT1_2 is not expressed, whereas in ALS patients, its level is increased. It can be found especially in the anterior horn of the spinal cord, leading to paraspeckle formation and further degeneration due to neurotoxicity $[120,121]$. Furthermore, NEAT1 has been linked to the accumulation of misfolded TAR DNA-binding protein 43 (TDP-43) in intracellular inclusions. There is, in fact, a clear co-localization and binding of NEAT1 and TDP-43 in cellular stress conditions, which can be found in cellular inclusions in some ALS cases [156]. Moreover, the same feature also underlies the pathophysiology of frontotemporal dementia (FTD), which is very often comorbid with ALS [106,151].

C9ORF72 is another example of an lncRNA associated with ALS (Table 1). It interacts with Rab proteins and controls endocytosis, autophagy and SG clearance. In ALS patients, it shows a significantly expanded number $(>30)$ of GGGGCC repeats between $1 \mathrm{a}$ and $2 \mathrm{~b}$ exons. After this transcript is translated, the protein loses its physiological function, which in healthy conditions, is linked to the regulation of endocytosis and autophagy $[151,160,161]$. Moreover, the extended number of hexanucleotide repeats of the sense and antisense RNA can co-localize with proteins involved in SGs formation, which is neurotoxic and leads to neurodegeneration (Figure 6) $[124,158,162]$. Additionally, the pathological repeats can be further translated into misfolded proteins, binding into toxic aggregates that can be found in the brain stem and spinal cord of some patients [158,163]. Finally, the repeat expansion can form a G-quadruplex structure that functions as a platform to recruit proteins such as TDP-43 and p62, forming pathological neuronal cytoplasmic inclusions [127]. C9ORF72 can additionally undergo LLPS by forming droplet-like cellular inclusions [126,164].

Sat III (stress-induced satellite III repeat RNA) encodes for another IncRNA overexpressed in ALS (Table 1). Some studies of its functional orthologue in Drosophila melanogaster, Hsr $\omega$, showed that this transcript bound the protein dFUS, which was involved in ALS pathogenesis and could also be present in toxic cellular inclusions containing aggregated proteins $[128,165]$. The knockdown of this lncRNA led to dFUS translocation to the cytoplasm, altering the functioning of the protein [126,164]. Furthermore, Hsrw was also linked to TDP-43 aggregates formation, as it enhanced the expression of the gene encoding for this protein [166]. 
A
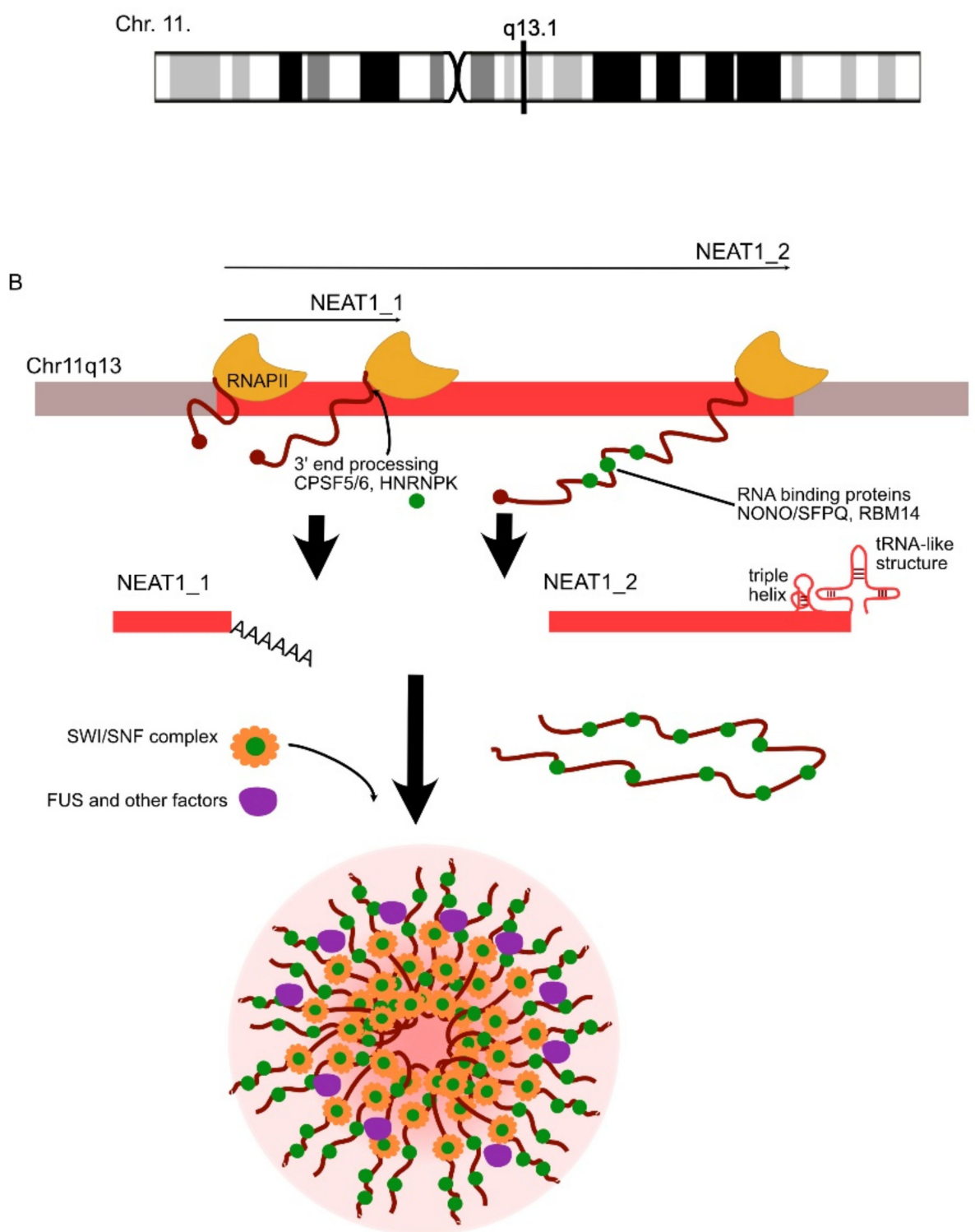

Figure 5. NEAT1 in paraspeckle formation. (A) The NEAT1 locus is localized on chromosome 11 (www.genecards.org, accessed on 28 April 2021). (B) NEAT1 can be transcribed by the RNAPII into NEAT_1 or NEAT_2 transcripts, which vary in the structure of their $3^{\prime}$ end. The dot at the $5^{\prime}$ end of each variant represents the structure of a cap. The triple helix and tRNA-like structure at the $3^{\prime}$-end of NEAT1_2 prevent the polyadenylation at the $3^{\prime}$-end of this isoform. HNRNPK (heterogeneous nuclear ribonucleoprotein $\mathrm{K}$ ) is a crucial factor for NEAT1_2 processing, as it prevents NEAT1_1 polyadenylation, which is dependent on SPSF5/6. NEAT1_2 additionally binds stabilizing PLD (phospholipase D)-containing, RNA-binding proteins such as NONO (non-POU domain-containing, octamer-binding protein), SFPQ (splicing factor, proline- and glutamine = rich) or RBM14 (RNA binding protein 14). The NEAT1 lncRNA is localized into the cellular inclusions along with SWI/SNF (SWItch/sucrose non-fermentable) complexes (made out of grouped stabilizing, PLD-containing proteins) and FUS and other PLD-containing proteins. 


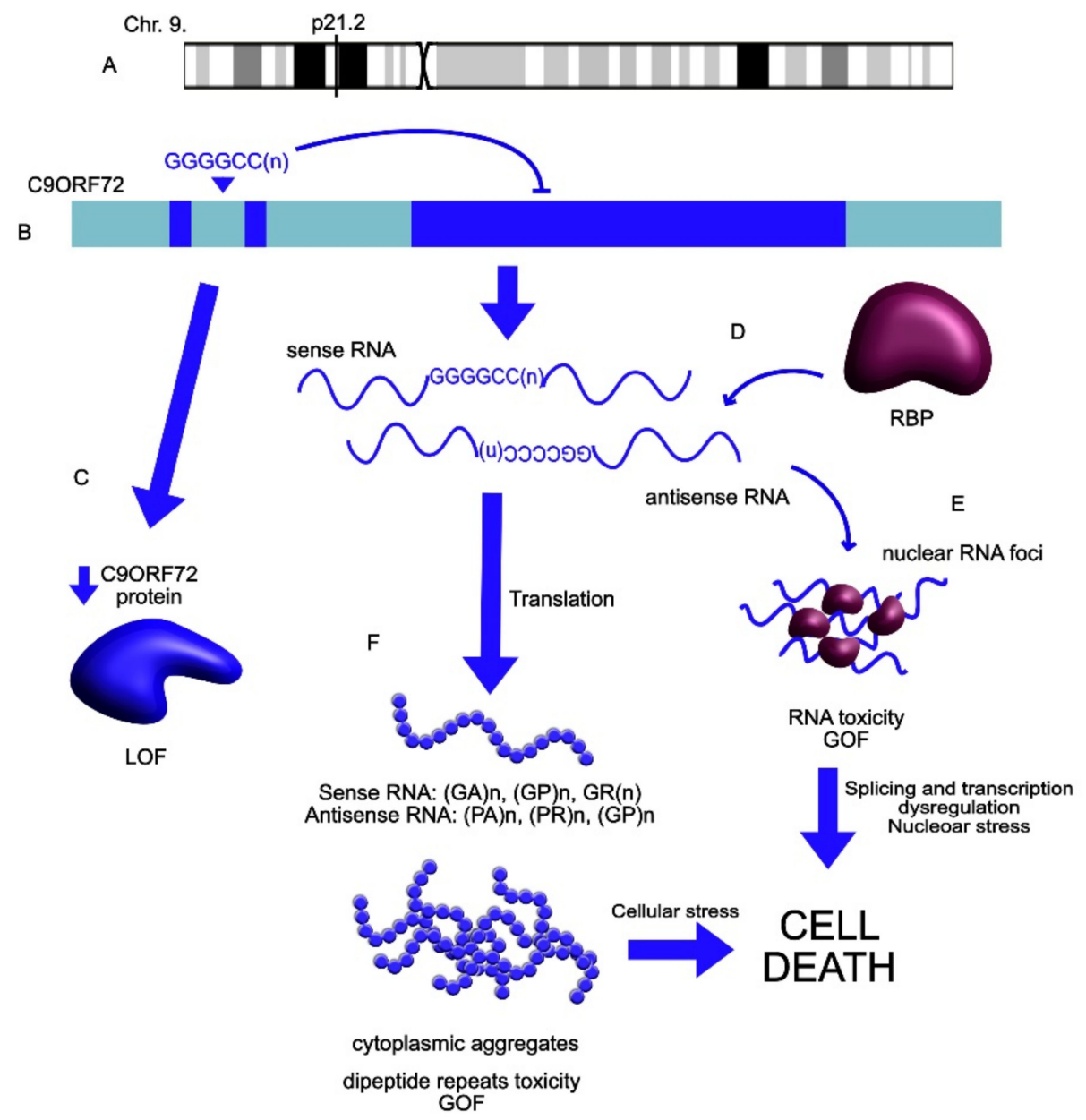

Figure 6. C9ORF72's role in ALS pathophysiology. (A) The C9ORF72 locus is localized on chromosome 9 (www.genecards.org, accessed on 28 April 2021). (B) In ALS patients, in C9ORF72, there have been observed a significantly extended number (>30) of GGGGCC repeats in the gene. (C) This mutation leads to impaired translation of the protein and its loss of function (LOF). (D) The sense and the antisense transcripts bind to RNA-binding proteins (RBP) forming nuclear foci and forming toxic aggregates (GOF: gain of function), which affects cellular processes such as splicing, transcription and nucleocytoplasmic transport and leads to nuclear stress $(\mathbf{E}, \mathbf{F})$. These transcripts are further translated into misfolded proteins, which can form toxic dipeptide aggregates (GOF). All the toxic cellular inclusions lead to cellular stress and eventually cell death (GA: glycine-alanine; GP: glycine-proline; GR: glycine-arginine; PA: proline-alanine; PR: proline-arginine; GP: glycine-proline).

\section{LncRNAs in Neurodevelopmental and Neuropsychiatric Disorders}

LncRNAs play a key role in neurogenesis, synaptogenesis and brain development. Thanks to high-throughput technologies, it is clear that they are expressed in specific cell types, subcellular compartments and different regions of the brain $[167,168]$. Many lncRNAs are expressed in an age-dependent manner [169] and participate in neural cell fate determination [65]. Because of their involvement in these processes, any aberrant expression of these transcripts may result in neurodevelopmental or neuropsychiatric disorders such as autism spectrum disorder (ASD) or schizophrenia (SZ), among many others (Table 2) [65,170]. During neurodevelopment and brain functioning, GABAergic transmission is fundamental. Studies have shown that disrupted functions of GABAergic interneurons and associated lncRNAs can be observed in both ASD and SZ [170]. LncRNAs are also involved in many other genetic syndromes resulting in altered neurodevelopment including Angelman syndrome, Rett syndrome, fragile X chromosome and Down syndrome, which are linked with a predisposition to intellectual disability and ASD 
features [52-57,170,171]. Moreover, some of these syndromes can be comorbid with other neurodevelopmental disorders, suggesting that they may share pathophysiology and some molecular pathways [170,171].

Table 2. LncRNAs dysregulated in neurodevelopmental and neuropsychiatric disorders. The chosen examples of lncRNAs are involved in neurodevelopmental and neuropsychiatric disorders. (UP: upregulation; DOWN: downregulation; references are shown).

\begin{tabular}{|c|c|c|c|c|}
\hline LncRNA & $\begin{array}{l}\text { Expression } \\
\text { Change }\end{array}$ & Role & Linked Disorder & References \\
\hline GOMAFU & DOWN & $\begin{array}{l}\text { GOMAFU controls alternative splicing through } \\
\text { interactions with splicing factors. Moreover, it } \\
\text { affects the specification of amacrine cells and is } \\
\text { involved in SZ-related eye movement disorder. }\end{array}$ & SZ & $\begin{array}{l}\text { Takahashi et al., 2003 [172]; } \\
\text { Rapicavoli et al., 2010 [173]; } \\
\text { Tsuiji et al., } 2011 \text { [95]; } \\
\text { Ip et al., } 2016 \text { [174] }\end{array}$ \\
\hline MALAT1 & DOWN & $\begin{array}{l}\text { MALAT1 controls the expression of genes } \\
\text { linked to synaptogenesis through interactions } \\
\text { with SR proteins. The downregulation of } \\
\text { MALAT1 leads to impaired formation of } \\
\text { synapses and reduced synaptic density. }\end{array}$ & SZ & $\begin{array}{l}\text { Bernard et al., } 2010 \text { [175]; } \\
\text { Madabhushi et al., } 2015 \text { [176] }\end{array}$ \\
\hline$D I S C 1-A S$ & DOWN & $\begin{array}{l}\text { DISC1-AS affects cAMP signaling through } \\
\text { interactions with DISC1 and DISC2. }\end{array}$ & $\mathrm{SZ}$ & $\begin{array}{l}\text { Millar et al., } 2004 \text { [177]; } \\
\text { Chubb et al., } 2008 \text { [178] }\end{array}$ \\
\hline$D I S C 2-A S$ & DOWN & $\begin{array}{l}\text { DISC2-AS affects cAMP signaling (through } \\
\text { interactions with DISC2), neuregulin signalling, } \\
\text { axonal signalling and also long-term synaptic } \\
\text { potentiation. }\end{array}$ & $\mathrm{SZ}$ & $\begin{array}{l}\text { Polesskaya et al., 2003 [179]; } \\
\text { Walsh et al., } 2008 \text { [180] }\end{array}$ \\
\hline NEAT1 & DOWN & $\begin{array}{l}\text { NEAT1 takes part in the unfolded proteins' } \\
\text { response under a condition of cellular stress. }\end{array}$ & SZ & $\begin{array}{l}\text { Nakagawa et al., } 2011 \text { [181]; } \\
\text { Hirose et al., } 2014 \text { [182] }\end{array}$ \\
\hline SHANK2-AS & DOWN & $\begin{array}{l}\text { SHANK2-AS affects the processes regulating } \\
\text { post-synaptic density through interactions } \\
\text { with SHANK2. }\end{array}$ & ASD & Wang et al., 2015 [183] \\
\hline$B D N F-A S$ & DOWN & $\begin{array}{l}B D N F-A S \text { inhibits the BDNF transcript, which } \\
\text { is a crucial transcription factor involved in } \\
\text { neurite functioning. }\end{array}$ & ASD & Wang et al., 2015 [183] \\
\hline PTCHD1AS1-3 & DOWN & $\begin{array}{l}\text { PTCHD1AS1-3 is linked to the dysfunction } \\
\text { of synapses and neurons in ASD. }\end{array}$ & ASD & Noor et al., 2010 [184] \\
\hline NRON & UP & $\begin{array}{l}\text { NRON inhibits NFAT (nuclear factor-activated } \\
\text { T-cell) signaling. }\end{array}$ & Major Depressive Disorder & Willingham et al., 2005 [85] \\
\hline AK081227 & UP & $\begin{array}{l}\text { AK081227 downregulates GABAergic signalling } \\
\text { through the inhibition of Gabrr2 expression. }\end{array}$ & Rett Syndrome & Petazzi et al., 2013 [54] \\
\hline Ube3aATS & DOWN & $\begin{array}{l}\text { Ube3aATS downregulation is associated with } \\
\text { impaired contextual fear behavior (in Angelman } \\
\text { syndrome). This is due to the impaired silencing of } \\
\text { paternal Ube3a. }\end{array}$ & Angelman Syndrome & $\begin{array}{l}\text { Meng et al., } 2012 \text { [185]; } \\
\text { Meng et al., } 2013 \text { [186]; } \\
\text { Meng et al., } 2015 \text { [187] }\end{array}$ \\
\hline
\end{tabular}

\subsection{Autism Spectrum Disorder}

ASD is a heterogeneous neurodevelopmental disorder that arises from defects and aberrant gene expression during development. Its clinical symptoms include various repetitive stereotyped behaviors and also defects in communication (verbal and non-verbal) and reciprocal social interactions [65]. The etiology of ASD is extremely complex, including both genetic and environmental influences. Studies showed that there were mutations linked to ASD that could range from single-nucleotide variants to copy number variants and chromosomal abnormalities that affected both coding and non-coding genes [188]. Because there is a vast heterogeneity of genetic components in ASD, and the brain tissue of patients cannot be used for clinical diagnostic purposes, this pathology is still being studied, and the role of lncRNAs is still yet to be fully investigated (Table 2). Several groups have tried to identify the expression profiles of dysregulated mRNAs and lncRNAs in peripheral leukocytes from the blood of patients in order to analyze in which pathways these transcripts are involved $[183,189]$. The studies confirmed that many dysregulated IncRNAs were associated with regulatory homeobox-related genes (HOXA and HOXB), which might have confirmed their important role in ASD pathophysiology. Moreover, Wang and colleagues [183] suggested that lncRNAs involved in synaptic vesicle trans- 
port/signaling and long-term potentiation and depression play a major role in ASD. The analysis of post-mortem human brain tissue (prefrontal cortex (PFC) and cerebellum) identified 222 aberrantly expressed lncRNAs in individuals with ASD compared to the control group. Moreover, there was relative homogeneity of lncRNA expression between the PFC and cerebellum in the post-mortem tissue of individuals with ASD compared to the control [55]. Most of these transcripts were associated with the protein-coding genes that were expressed throughout neurogenesis and brain development [190-192]. An example is the gene coding of the ubiquitin protein ligase E3A $(U B E 3 A)$, which is also disrupted in Angelman syndrome, which shares some clinical symptoms with ASD [109,170,193-195]. Thirty-eight lncRNAs have been identified as the antisense transcripts to protein-coding genes already linked with ASD such as SYNGAP1-AS, which is shown to be upregulated in the post-mortem PFC of individuals with ASD $[3,65,196]$.

Other studies showed that a certain single nucleotide polymorphism in the antisense transcript to a processed pseudogene of moesin (MSNP1AS) also could be present and upregulated in some ASD cases [197]. This lncRNA regulates the expression of moesin, which is an important factor in neurons regulating the immune response and architecture of the nucleus $[3,65,198,199]$. Upregulation of MSNP1AS leads to downregulation of moesin translation, negatively affecting neurite morphology and function [65,170,198,199].

$S H A N K 2-A S$, the antisense transcript of SH3 and multiple-ankyrin repeat-domains protein 2, and $B D N F-A S$, the antisense to the brain-derived neurotrophic factor, represent other examples of the antisense lncRNAs associated with ASD (Table 2) [183,200-202]. Most of these identified antisense transcripts were associated with regulatory homeoboxrelated genes (HOXA and $H O X B)$, some of whose mRNAs were also found to be aberrantly expressed.

\subsection{Schizophrenia}

$\mathrm{SZ}$ is a developmental neuropsychiatric disorder affecting up to $1 \%$ of the population. This disease is characterized by positive symptoms such as delusions, hallucinations and psychosis and negative symptoms such as depression, apathy and dysphoria. The exact etiology of SZ is not yet known. However, it seems that there are strong influences from genetics, epigenetics and the environment $[65,188,203]$.

One of the lncRNAs most frequently linked with SZ is the nuclear transcript GOMAFU (Table 2) [23]. This lncRNA competitively binds to various miRNA and splicing factors, resulting in the decreased translation of SZ-linked mRNA $[49,204]$. In SZ post-mortem brain tissue, it was found that the GOMAFU expression level was significantly lower compared to the control. This downregulation has a very serious effect because it regulates splicing factors QKI (quaking homolog) and SRSF1 (serine/arginine-rich splicing factor 1), with global consequences on alternative splicing (Figure 7 ) $[3,23,50]$. It also upregulates two SZ-linked genes: DISC1 (disrupted in schizophrenia 1) and ERBB4 (v-erb-a erythroblastic leukemia viral oncogene homolog 4) [178,192,205]. GOMAFU knockdown results in splicing variants of these genes, similar to the ones observed in patients. Interestingly, the overexpression of GOMAFU in iPSCs resulted in the downregulation of the SZ-related splice variants of DISC1 and ERBB4. This lncRNA has also been studied in the context of anxiety-related behavior (also occurring in SZ), as its levels are downregulated in the medial prefrontal cortex, impacting fear conditioning in mice. Mice with GOMAFU knockdown additionally present higher anxiety levels and fear-related behavior. While mice did not present any significant developmental abnormalities, they did present aberrations in their behavior and "wellbeing", which might have suggested that even the slightest impact of GOMAFU function on neurodevelopment could result in significant behavioral changes $[23,50,65,188,192]$. Furthermore, GOMAFU takes part in the regulation of many other processes such as cell proliferation, migration and apoptosis through competitive interactions with various miRNAs $[96,99,192,203]$. 


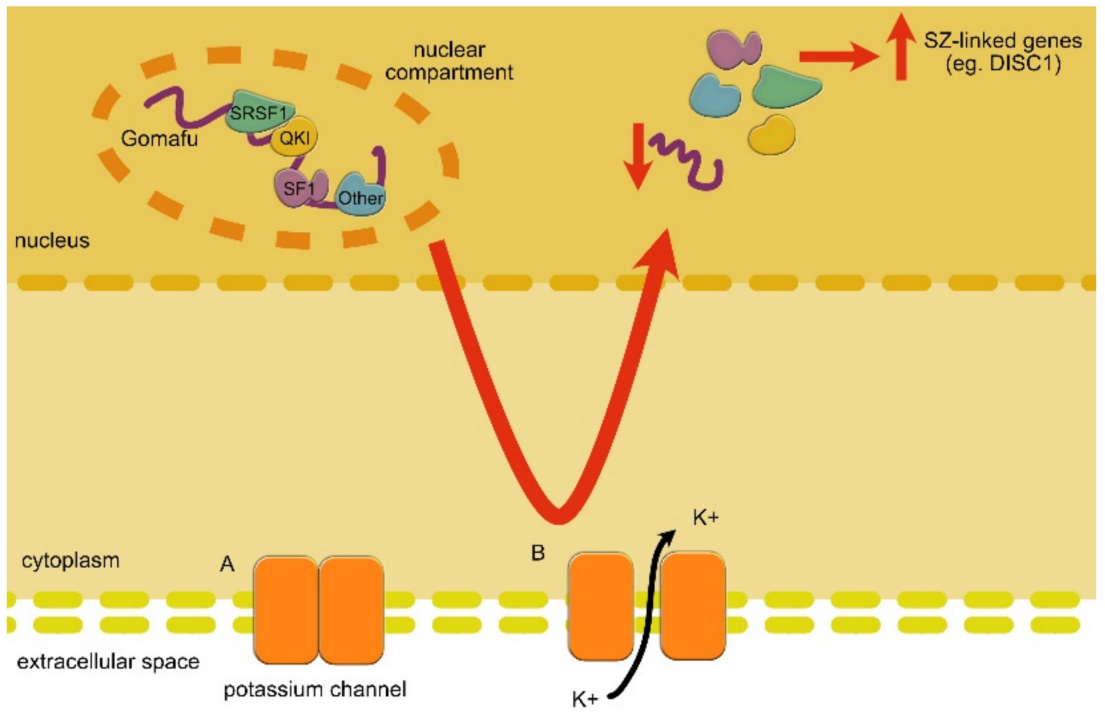

Figure 7. GOMAFU (MIAT) involvement in alternative splicing and SZ. When the cell is in an inactive state, the potassium channels $(\mathrm{K}+)$ are closed, and GOMAFU can bind several splicing factors (QKI; quaking homolog; SF1: splicing factor 1; SRSF1: serine/arginine rich SF1) involved in the expression of the SZ-related genes. In this way, it functional alternative splicing resulting in the decreased production of SZ-related proteins. When the cell becomes active, however, the ion channels open, and the influx of $\mathrm{K}+$ ions leads to GOMAFU transcription downregulation (which is significantly decreased in SZ). The splicing factors are, therefore, free to act toward the alternative splicing of SZ-linked genes.

The DISC1-AS lncRNA has been linked to SZ (Table 2), as it negatively regulates DISC1 expression [65,188,192]. DLG2AS (antisense to discs large homolog 2) dysregulation has also been found in SZ patients' brains. Through the control of DLG2 gene expression (downregulated in the hippocampus of SZ patients), these lncRNAs impact brain development, long-term synaptic potentiation and axonal guidance signaling [188].

LncRNAs associated with the nuclear factor- $\mathrm{KB}(\mathrm{NF}-\mathrm{kB}$ ) protein family have also been linked with SZ pathophysiology. This protein family has an important role in neurodevelopment, interacting with crucial genes/pathways for neurogenesis such as Notch, Shh and Wnt, and it also regulates inflammatory response [206]. In SZ patients, both NF-kB and genes that direct its translocation are downregulated, especially in the superior temporal gyrus. Safa and colleagues [206] showed that the dysregulated levels of lncRNAs associated with NF- $\mathrm{kB}$ could be found in the blood plasma of SZ patients. Most of these transcripts were upregulated in samples from the SZ group and might have been related to higher immune activation in the cortical regions. Moreover, most of these lncRNAs along the NF- $\mathrm{KB}$ pathway were involved in neurogenesis, synaptogenesis and brain development; hence, they may have played a role in the development of various neurological disorders including SZ [188,192,206].

\section{Final Remarks}

LncRNAs regulate several processes during brain development, neurogenesis, cell fate decision, maturation and differentiation [26] and are involved in cognitive mechanisms and memory formation [26]. Because lncRNAs act at different levels, any variation of their expression can result in developmental defects and neurological and psychiatric disorders [52]. One of the challenges in this field is to better understand the mechanisms of action of lncRNAs, the pathways in which they are involved and the partners with which they act during development. A more in-depth study of lncRNA and coding genes/genome architecture relationships could broaden the knowledge on the emerging link between neurodevelopmental defects and neurodegenerative phenotypes. Furthermore, understanding the roles of lncRNA-driven epigenetic modifications is also of pivotal importance 
for tailored treatments. It is therefore extremely necessary to develop adequate genetic tools and establish animal and in vitro models to study in detail the networks of lncRNAs and their alterations in disease. To date, only a small percentage of lncRNAs have been studied in pathological processes. With our review, we aimed to further stimulate lncRNA research in neurological and neurodevelopmental disorders for a broader understanding of disease and for implementing novel, RNA-based therapeutic approaches.

Author Contributions: Conceptualization, V.A., J.S. and A.C.; writing-original draft preparation, V.A., J.S. and A.C.; writing-review and editing, V.A., J.S. and A.C.; funding acquisition, A.C. All authors have read and agreed to the published version of the manuscript.

Funding: A.C. is funded by the Rett Syndrome Research Trust (RSRT), two BARTS CHARITY grants and intramural QMUL support.

Institutional Review Board Statement: Not applicable.

Informed Consent Statement: Not applicable.

Acknowledgments: Let us apologize for the excellent work that could not be included in this review due to space and focus reasons. We thank Zak Ahmad for the English proofreading of this manuscript.

Conflicts of Interest: The authors declare no conflict of interest.

\section{References}

1. Gomes, A.Q.; Nolasco, S.; Soares, H. Non-Coding RNAs: Multi-Tasking Molecules in the Cell. Int. J. Mol. Sci. 2013, 14, 16010-16039. [CrossRef] [PubMed]

2. Derrien, T.; Johnson, R.; Bussotti, G.; Tanzer, A.; Djebali, S.; Tilgner, H.; Guernec, G.; Martin, D.; Merkel, A.; Knowles, D.G.; et al. The GENCODE v7 catalog of human long noncoding RNAs: Analysis of their gene structure, evolution, and expression. Genome Res. 2012, 22, 1775-1789. [CrossRef]

3. Roberts, T.C.; Morris, K.V.; Wood, M.J.A. The role of long non-coding RNAs in neurodevelopment, brain function and neurological disease. Philos. Trans. R. Soc. B Biol. Sci. 2014, 369, 20130507. [CrossRef] [PubMed]

4. Lekka, E.; Hall, J. Noncoding RNA s in disease. FEBS Lett. 2018, 592, 2884-2900. [CrossRef]

5. Chen, K.-W.; Chen, J.-A. Functional Roles of Long Non-coding RNAs in Motor Neuron Development and Disease. J. Biomed. Sci. 2020, 27, 38. [CrossRef]

6. Clark, M.B.; Amaral, P.D.P.; Schlesinger, F.J; Dinger, M.; Taft, R.J.; Rinn, J.L.; Ponting, C.P.; Stadler, P.F.; Morris, K.V.; Morillon, A.; et al. The Reality of Pervasive Transcription. PLoS Biol. 2011, 9, e1000625. [CrossRef] [PubMed]

7. Kung, J.T.Y.; Colognori, D.; Lee, J.T. Long Noncoding RNAs: Past, Present, and Future. Genetics 2013, 193, 651-669. [CrossRef] [PubMed]

8. Beermann, J.; Piccoli, M.-T.; Viereck, J.; Thum, T. Non-coding RNAs in Development and Disease: Background, Mechanisms, and Therapeutic Approaches. Physiol. Rev. 2016, 96, 1297-1325. [CrossRef]

9. Chen, X.; Yan, C.C.; Zhang, X.; You, Z.-H. Long non-coding RNAs and complex diseases: From experimental results to computational models. Brief. Bioinform. 2016, 18, 558-576. [CrossRef] [PubMed]

10. Distefano, J.K. The Emerging Role of Long Noncoding RNAs in Human Disease. Methods Mol. Biol. 2018, 1706, 91-110. [CrossRef] [PubMed]

11. Chen, C.; Tang, Y.; Sun, H.; Lin, X.; Jiang, B. The roles of long noncoding RNAs in myocardial pathophysiology. Biosci. Rep. 2019, 39, 20190966. [CrossRef] [PubMed]

12. Chen, J.; Ao, L.; Yang, J. Long non-coding RNAs in diseases related to inflammation and immunity. Ann. Transl. Med. 2019, 7, 494. [CrossRef] [PubMed]

13. Fernandes, J.C.R.; Acuña, S.M.; Aoki, J.I.; Floeter-Winter, L.M.; Muxel, S.M. Long Non-Coding RNAs in the Regulation of Gene Expression: Physiology and Disease. Non-Coding RNA 2019, 5, 17. [CrossRef] [PubMed]

14. Mongelli, A.; Martelli, F.; Farsetti, A.; Gaetano, C. The Dark That Matters: Long Non-coding RNAs as Master Regulators of Cellular Metabolism in Non-communicable Diseases. Front. Physiol. 2019, 10, 369. [CrossRef]

15. Sparber, P.; Filatova, A.; Khantemirova, M.; Skoblov, M. The role of long non-coding RNAs in the pathogenesis of hereditary diseases. BMC Med. Genom. 2019, 12 (Suppl. S2), 42. [CrossRef]

16. Jaé, N.; Dimmeler, S. Noncoding RNAs in Vascular Diseases. Circ. Res. 2020, 126, 1127-1145. [CrossRef]

17. Sun, B.; Liu, C.; Zhang, L.; Luo, G.; Liang, S. Research progress on the interactions between long non-coding RNAs and microRNAs in human cancer (Review). Oncol. Lett. 2019, 19, 595-605. [CrossRef] [PubMed]

18. Wijesinghe, S.N.; Nicholson, T.; Tsintzas, K.; Jones, S.W. Involvements of long noncoding RNAs in obesity-associated inflammatory diseases. Obes. Rev. 2021, 22, 13156. [CrossRef] [PubMed]

19. Qureshi, I.A.; Mehler, M.F. Emerging roles of non-coding RNAs in brain evolution, development, plasticity and disease. Nat. Rev. Neurosci. 2012, 13, 528-541. [CrossRef] [PubMed] 
20. Dahariya, S.; Paddibhatla, I.; Kumar, S.; Raghuwanshi, S.; Pallepati, A.; Gutti, R.K. Long non-coding RNA: Classification, biogenesis and functions in blood cells. Mol. Immunol. 2019, 112, 82-92. [CrossRef] [PubMed]

21. Nie, L.; Wu, H.-J.; Hsu, J.-M.; Chang, S.-S.; Labaff, A.M.; Li, C.-W.; Wang, Y.; Hsu, J.L.; Hung, M.-C. Long non-coding RNAs: Versatile master regulators of gene expression and crucial players in cancer. Am. J. Transl. Res. 2012, 4, 127-150.

22. Tuck, A.C.; Tollervey, D. RNA in pieces. Trends Genet. 2011, 27, 422-432. [CrossRef] [PubMed]

23. Andersen, R.; Lim, D.A. Forging our understanding of lncRNAs in the brain. Cell Tissue Res. 2018, 371, 55-71. [CrossRef] [PubMed]

24. Saxena, A.; Carninci, P. Long non-coding RNA modifies chromatin: Epigenetic silencing by long non-coding RNAs. BioEssays 2011, 33, 830-839. [CrossRef]

25. Mercer, T.R.; Mattick, J.S. Structure and function of long noncoding RNAs in epigenetic regulation. Nat. Struct. Mol. Biol. 2013, 20, 300-307. [CrossRef] [PubMed]

26. Wu, P.; Zuo, X.; Deng, H.; Liu, X.; Liu, L.; Ji, A. Roles of long noncoding RNAs in brain development, functional diversification and neurodegenerative diseases. Brain Res. Bull. 2013, 97, 69-80. [CrossRef] [PubMed]

27. Tsagakis, I.; Douka, K.; Birds, I.; Aspden, J.L. Long non-coding RNAs in development and disease: Conservation to mechanisms. J. Pathol. 2020, 250, 480-495. [CrossRef]

28. Zhang, L.; Dong, Y.; Wang, Y.; Gao, J.; Lv, J.; Sun, J.; Li, M.; Wang, M.; Zhao, Z.; Wang, J.; et al. Long non-codingRNAs in ocular diseases: New and potential therapeutic targets. FEBS J. 2019, 286, 2261-2272. [CrossRef]

29. Wan, P.; Su, W.; Zhuo, Y. The Role of Long Noncoding RNAs in Neurodegenerative Diseases. Mol. Neurobiol. 2016, 54, $2012-2021$. [CrossRef] [PubMed]

30. Dykes, I.M.; Emanueli, C. Transcriptional and Post-transcriptional Gene Regulation by Long Non-coding RNA. Genom. Proteom. Bioinform. 2017, 15, 177-186. [CrossRef] [PubMed]

31. Ponjavic, J.; Ponting, C.P.; Lunter, G. Functionality or transcriptional noise? Evidence for selection within long noncoding RNAs. Genome Res. 2007, 17, 556-565. [CrossRef] [PubMed]

32. Nesterova, T.B.; Slobodyanyuk, S.Y.; Elisaphenko, E.A.; Shevchenko, A.I.; Johnston, C.; Pavlova, M.E.; Rogozin, I.B.; Kolesnikov, N.N.; Brockdorff, N.; Zakian, S.M. Characterization of the Genomic Xist Locus in Rodents Reveals Conservation of Overall Gene Structure and Tandem Repeats but Rapid Evolution of Unique Sequence. Genome Res. 2001, 11, 833-849. [CrossRef]

33. Chodroff, R.A.; Goodstadt, L.; Sirey, T.M.; Oliver, P.L.; Davies, K.E.; Green, E.D.; Molnár, Z.; Ponting, C.P. Long noncoding RNA genes: Conservation of sequence and brain expression among diverse amniotes. Genome Biol. 2010, 11, R72. [CrossRef] [PubMed]

34. Kirk, J.M.; Kim, S.O.; Inoue, K.; Smola, M.J.; Lee, D.M.; Schertzer, M.; Wooten, J.S.; Baker, A.R.; Sprague, D.; Collins, D.W.; et al Functional classification of long non-coding RNAs by k-mer content. Nat. Genet. 2018, 50, 1474-1482. [CrossRef] [PubMed]

35. Sprague, D.; Waters, S.; Kirk, J.M.; Wang, J.R.; Samollow, P.B.; Waters, P.D.; Calabrese, J.M. Nonlinear sequence similarity between the Xist and Rsx long noncoding RNAs suggests shared functions of tandem repeat domains. RNA 2019, 25, 1004-1019. [CrossRef] [PubMed]

36. Smith, K.N.; Miller, S.C.; Varani, G.; Calabrese, J.M.; Magnuson, T. Multimodal Long Noncoding RNA Interaction Networks: Control Panels for Cell Fate Specification. Genet. 2019, 213, 1093-1110. [CrossRef] [PubMed]

37. Chillón, I.; Marcia, M. The molecular structure of long non-coding RNAs: Emerging patterns and functional implications. Crit. Rev. Biochem. Mol. Biol. 2020, 55, 662-690. [CrossRef] [PubMed]

38. Wutz, A.; Rasmussen, T.; Jaenisch, R. Chromosomal silencing and localization are mediated by different domains of Xist RNA. Nat. Genet. 2002, 30, 167-174. [CrossRef] [PubMed]

39. Fang, R.; Moss, W.N.; Rutenberg-Schoenberg, M.; Simon, M.D. Probing Xist RNA Structure in Cells Using Targeted Structure-Seq. PLoS Genet. 2015, 11, e1005668. [CrossRef]

40. Smola, M.J.; Christy, T.W.; Inoue, K.; Nicholson, C.O.; Friedersdorf, M.; Keene, J.D.; Lee, D.M.; Calabrese, J.M.; Weeks, K.M. SHAPE reveals transcript-wide interactions, complex structural domains, and protein interactions across the Xist lncRNA in living cells. Proc. Natl. Acad. Sci. USA 2016, 113, 10322-10327. [CrossRef]

41. Liu, F.; Somarowthu, S.; Pyle, A.M. Visualizing the secondary and tertiary architectural domains of lncRNA RepA. Nat. Chem. Biol. 2017, 13, 282-289. [CrossRef] [PubMed]

42. Somarowthu, S.; Legiewicz, M.; Chillón, I.; Marcia, M.; Liu, F.; Pyle, A.M. HOTAIR Forms an Intricate and Modular Secondary Structure. Mol. Cell 2015, 58, 353-361. [CrossRef] [PubMed]

43. Chillón, I.; Pyle, A.M. Inverted repeat Alu elements in the human lincRNA-p21 adopt a conserved secondary structure that regulates RNA function. Nucleic Acids Res. 2016, 44, 9462-9471. [CrossRef]

44. Pintacuda, G.; Young, A.N.; Cerase, A. Function by Structure: Spotlights on Xist Long Non-coding RNA. Front. Mol. Biosci. 2017, 4, 90. [CrossRef]

45. Cirillo, D.; Blanco, M.; Armaos, A.; Buness, A.; Avner, P.; Guttman, M.; Cerase, A.; Tartaglia, G.G. Quantitative predictions of protein interactions with long noncoding RNAs. Nat. Methods 2017, 14, 5-6. [CrossRef]

46. Clark, M.B.; Johnston, R.L.; Inostroza-Ponta, M.; Fox, A.H.; Fortini, E.; Moscato, P.; Dinger, M.E.; Mattick, J.S. Genome-wide analysis of long noncoding RNA stability. Genome Res. 2012, 22, 885-898. [CrossRef] [PubMed]

47. Mercer, T.R.; Dinger, M.; Mattick, J.S. Long non-coding RNAs: Insights into functions. Nat. Rev. Genet. 2009, 10, 155-159. [CrossRef] [PubMed] 
48. Pagani, M.; Rossetti, G.; Panzeri, I.; De Candia, P.; Bonnal, R.J.P.; Rossi, R.L.; Geginat, J.; Abrignani, S. Role of microRNAs and long-non-coding RNAs in CD4+T-cell differentiation. Immunol. Rev. 2013, 253, 82-96. [CrossRef] [PubMed]

49. Geisler, S.; Coller, J. RNA in unexpected places: Long non-coding RNA functions in diverse cellular contexts. Nat. Rev. Mol. Cell Biol. 2013, 14, 699-712. [CrossRef] [PubMed]

50. Clark, B.; Eblackshaw, S. Long non-coding RNA-dependent transcriptional regulation in neuronal development and disease. Front. Genet. 2014, 5, 164. [CrossRef]

51. Park, J.Y.; Lee, J.E.; Park, J.B.; Yoo, H.; Lee, S.-H.; Kim, J.H. Roles of Long Non-Coding RNAs on Tumorigenesis and Glioma Development. Brain Tumor Res. Treat. 2014, 2, 1-6. [CrossRef] [PubMed]

52. Van De Vondervoort, I.I.G.M.; Gordebeke, P.M.; Ekhoshab, N.; Tiesinga, P.H.E.; Buitelaar, J.K.; Ekozicz, T.; Easchrafi, A.; Glennon, J.C. Long non-coding RNAs in neurodevelopmental disorders. Front. Mol. Neurosci. 2013, 6, 53. [CrossRef] [PubMed]

53. Taft, R.J.; Pang, K.C.; Mercer, T.R.; Dinger, M.; Mattick, J.S. Non-coding RNAs: Regulators of disease. J. Pathol. 2009, 220 , 126-139. [CrossRef] [PubMed]

54. Petazzi, P.; Sandoval, J.; Szczesna, K.; Jorge, O.C.; Roa, L.; Sayols, S.; Gomez, A.; Huertas, D.; Esteller, M. Dysregulation of the long non-coding RNA transcriptome in a Rett syndrome mouse model. RNA Biol. 2013, 10, 1197-1203. [CrossRef]

55. Ziats, M.N.; Rennert, O.M. Aberrant Expression of Long Noncoding RNAs in Autistic Brain. J. Mol. Neurosci. 2012, 49, 589-593. [CrossRef] [PubMed]

56. Pastori, C.; Peschansky, V.; Barbouth, D.; Mehta, A.; Silva, J.P.; Wahlestedt, C. Comprehensive analysis of the transcriptional landscape of the human FMR1 gene reveals two new long noncoding RNAs differentially expressed in Fragile X syndrome and Fragile X-associated tremor/ataxia syndrome. Hum. Genet. 2014, 133, 59-67. [CrossRef]

57. Zhang, S.-F.; Gao, J.; Liu, C.-M. The Role of Non-Coding RNAs in Neurodevelopmental Disorders. Front. Genet. $2019,10,1033$. [CrossRef] [PubMed]

58. Bánfai, B.; Jia, H.; Khatun, J.; Wood, E.; Risk, B.; Gundling, W.E.; Kundaje, A.; Gunawardena, H.P.; Yu, Y.; Xie, L.; et al. Long noncoding RNAs are rarely translated in two human cell lines. Genome Res. 2012, 22, 1646-1657. [CrossRef] [PubMed]

59. Guttman, M.; Russell, P.; Ingolia, N.T.; Weissman, J.S.; Lander, E.S. Ribosome Profiling Provides Evidence that Large Noncoding RNAs Do Not Encode Proteins. Cell 2013, 154, 240-251. [CrossRef] [PubMed]

60. Hangauer, M.J.; Vaughn, I.W.; McManus, M.T. Pervasive Transcription of the Human Genome Produces Thousands of Previously Unidentified Long Intergenic Noncoding RNAs. PLoS Genet. 2013, 9, e1003569. [CrossRef] [PubMed]

61. Bazzini, A.A.; Johnstone, T.; Christiano, R.; Mackowiak, S.; Obermayer, B.; Fleming, E.S.; Vejnar, C.E.; Lee, M.T.; Rajewsky, N.; Walther, T.; et al. Identification of small ORFs in vertebrates using ribosome footprinting and evolutionary conservation. EMBO J. 2014, 33, 981-993. [CrossRef]

62. Ruiz-Orera, J.; Messeguer, X.; Subirana, J.; Alba, M.M. Long non-coding RNAs as a source of new peptides. eLife 2014, 3, e03523. [CrossRef]

63. Vance, K.W.; Ponting, C.P. Transcriptional regulatory functions of nuclear long noncoding RNAs. Trends Genet. 2014, 30 , $348-355$. [CrossRef] [PubMed]

64. Bhat, S.A.; Ahmad, S.M.; Mumtaz, P.T.; Malik, A.A.; Dar, M.A.; Urwat, U.; Shah, R.A.; Ganai, N. Long non-coding RNAs: Mechanism of action and functional utility. Non-Coding RNA Res. 2016, 1, 43-50. [CrossRef] [PubMed]

65. Li, L.; Zhuang, Y.; Zhao, X.; Li, X. Long Non-coding RNA in Neuronal Development and Neurological Disorders. Front. Genet. 2019, 9, 744. [CrossRef]

66. Wang, K.C.; Chang, H.Y. Molecular Mechanisms of Long Noncoding RNAs. Mol. Cell 2011, 43, 904-914. [CrossRef]

67. Fang, Y.; Fullwood, M.J. Roles, Functions, and Mechanisms of Long Non-coding RNAs in Cancer. Genom. Proteom. Bioinform. 2016, 14, 42-54. [CrossRef] [PubMed]

68. Tripathi, V.; Ellis, J.D.; Shen, Z.; Song, D.Y.; Pan, Q.; Watt, A.T.; Freier, S.M.; Bennett, C.F.; Sharma, A.; Bubulya, P.A.; et al. The Nuclear-Retained Noncoding RNA MALAT1 Regulates Alternative Splicing by Modulating SR Splicing Factor Phosphorylation. Mol. Cell 2010, 39, 925-938. [CrossRef]

69. Gong, C.; Maquat, L.E. lncRNAs transactivate STAU1-mediated mRNA decay by duplexing with 3’ UTRs via Alu elements. Nature 2011, 470, 284-288. [CrossRef] [PubMed]

70. Carrieri, C.; Cimatti, L.; Biagioli, M.; Beugnet, A.; Zucchelli, S.; Fedele, S.; Pesce, E.; Ferrer, I.; Collavin, L.; Santoro, C.; et al. Long non-coding antisense RNA controls Uchl1 translation through an embedded SINEB2 repeat. Nature 2012, 491, 454-457. [CrossRef]

71. Faghihi, M.A.; Zhang, M.; Huang, J.; Modarresi, F.; Van Der Brug, M.P.; Nalls, M.A.; Cookson, M.R.; St-Laurent, G.; Wahlestedt, C. Evidence for natural antisense transcript-mediated inhibition of microRNA function. Genome Biol. 2010, 11, R56. [CrossRef]

72. Gudenas, B.L.; Wang, L. Prediction of LncRNA Subcellular Localization with Deep Learning from Sequence Features. Sci. Rep. 2018, 8, 16385. [CrossRef] [PubMed]

73. Zhang, B.; Gunawardane, L.; Niazi, F.; Jahanbani, F.; Chen, X.; Valadkhan, S. A Novel RNA Motif Mediates the Strict Nuclear Localization of a Long Noncoding RNA. Mol. Cell. Biol. 2014, 34, 2318-2329. [CrossRef] [PubMed]

74. Ahmad, A.; Lin, H.; Shatabda, S. Locate-R: Subcellular localization of long non-coding RNAs using nucleotide compositions. Genomics 2020, 112, 2583-2589. [CrossRef]

75. Cerase, A.; Tartaglia, G.G. Long non-coding RNA-polycomb intimate rendezvous. Open Biol. 2020, 10, 200126. [CrossRef] [PubMed] 
76. Fejes-Toth, K.; Sotirova, V.; Sachidanandam, R.; Assaf, G.; Hannon, G.J.; Kapranov, P.; Foissac, S.; Willingham, A.T.; Duttagupta, R.; Dumais, E.; et al. Post-transcriptional processing generates a diversity of $5^{\prime}$-modified long and short RNAs. Nature 2009, 457, 1028-1032. [CrossRef]

77. Kapranov, P.; Laurent, G.S.; Raz, T.; Ozsolak, F.; Reynolds, C.P.; Sorensen, P.H.B.; Reaman, G.; Milos, P.; Arceci, R.J.; Thompson, J.F.; et al. The majority of total nuclear-encoded non-ribosomal RNA in a human cell is 'dark matter' un-annotated RNA. BMC Biol. 2010, 8, 1. [CrossRef] [PubMed]

78. Poynter, S.T.; Kadoch, C. Polycomb and trithorax opposition in development and disease. Wiley Interdiscip. Rev. Dev. Biol. 2016, 5, 659-688. [CrossRef] [PubMed]

79. Schuettengruber, B.; Bourbon, H.-M.; Di Croce, L.; Cavalli, G. Genome Regulation by Polycomb and Trithorax: 70 Years and Counting. Cell 2017, 171, 34-57. [CrossRef]

80. Statello, L.; Guo, C.-J.; Chen, L.-L.; Huarte, M. Gene regulation by long non-coding RNAs and its biological functions. Nat. Rev. Mol. Cell Biol. 2021, 22, 96-118. [CrossRef]

81. Lee, J.T. Gracefully ageing at 50, X-chromosome inactivation becomes a paradigm for RNA and chromatin control. Nat. Rev. Mol. Cell Biol. 2011, 12, 815-826. [CrossRef] [PubMed]

82. Bousard, A.; Raposo, A.C.; Żylicz, J.J.; Picard, C.; Pires, V.B.; Qi, Y.; Gil, C.; Syx, L.; Chang, H.Y.; Heard, E.; et al. The role of Xist -mediated Polycomb recruitment in the initiation of X-chromosome inactivation. EMBO Rep. 2019, 20, e48019. [CrossRef]

83. Dixon-McDougall, T.; Brown, C.J. Independent domains for recruitment of PRC1 and PRC2 by human XIST. PLoS Genet. 2021, 17, e1009123. [CrossRef] [PubMed]

84. Wang, C.-Y.; Colognori, D.; Sunwoo, H.; Wang, D.; Lee, J.T. PRC1 collaborates with SMCHD1 to fold the X-chromosome and spread Xist RNA between chromosome compartments. Nat. Commun. 2019, 10, 2950. [CrossRef]

85. Willingham, A.T.; Orth, A.P.; Batalov, S.; Peters, E.C.; Wen, B.G.; Aza-Blanc, P.; Hogenesch, J.B.; Schultz, P.G. A Strategy for Probing the Function of Noncoding RNAs Finds a Repressor of NFAT. Science 2005, 309, 1570-1573. [CrossRef] [PubMed]

86. Shamovsky, I.; Ivannikov, M.; Kandel, E.S.; Gershon, D.; Nudler, E. RNA-mediated response to heat shock in mammalian cells. Nature 2006, 440, 556-560. [CrossRef]

87. Feng, J.; Bi, C.; Clark, B.; Mady, R.; Shah, P.; Kohtz, J.D. The Evf-2 noncoding RNA is transcribed from the Dlx-5/6 ultraconserved region and functions as a Dlx-2 transcriptional coactivator. Genes Dev. 2006, 20, 1470-1484. [CrossRef]

88. Tsai, M.-C.; Manor, O.; Wan, Y.; Mosammaparast, N.; Wang, J.K.; Lan, F.; Shi, Y.; Segal, E.; Chang, H.Y. Long Noncoding RNA as Modular Scaffold of Histone Modification Complexes. Science 2010, 329, 689-693. [CrossRef]

89. Turner, M.; Galloway, A.; Vigorito, E. Noncoding RNA and its associated proteins as regulatory elements of the immune system. Nat. Immunol. 2014, 15, 484-491. [CrossRef]

90. Sado, T.; Hoki, Y.; Sasaki, H. Tsix Silences Xist through Modification of Chromatin Structure. Dev. Cell 2005, 9, 159-165. [CrossRef] [PubMed]

91. Briggs, J.A.; Wolvetang, E.J.; Mattick, J.S.; Rinn, J.L.; Barry, G. Mechanisms of Long Non-coding RNAs in Mammalian Nervous System Development, Plasticity, Disease, and Evolution. Neuron 2015, 88, 861-877. [CrossRef]

92. Romero-Barrios, N.; Legascue, M.F.; Benhamed, M.; Ariel, F.; Crespi, M. Splicing regulation by long noncoding RNAs. Nucleic Acids Res. 2018, 46, 2169-2184. [CrossRef] [PubMed]

93. Zimmer-Bensch, G. Emerging Roles of Long Non-Coding RNAs as Drivers of Brain Evolution. Cells 2019, 8, 1399. [CrossRef] [PubMed]

94. Cooper, D.R.; Carter, G.; Li, P.; Patel, R.; Watson, J.E.; Patel, N.A. Long Non-Coding RNA NEAT1 Associates with SRp40 to Temporally Regulate PPAR 22 Splicing during Adipogenesis in 3T3-L1 Cells. Genes 2014, 5, 1050-1063. [CrossRef] [PubMed]

95. Tsuiji, H.; Yoshimoto, R.; Hasegawa, Y.; Furuno, M.; Yoshida, M.; Nakagawa, S. Competition between a noncoding exon and introns: Gomafu contains tandem UACUAAC repeats and associates with splicing factor-1. Genes Cells 2011, 16, 479-490. [CrossRef]

96. Yoshimoto, R.; Mayeda, A.; Yoshida, M.; Nakagawa, S. MALAT1 long non-coding RNA in cancer. Biochim. Biophys. Acta 2016, 1859, 192-199. [CrossRef] [PubMed]

97. Faghihi, M.A.; Modarresi, F.; Khalil, A.M.; Wood, D.E.; Sahagan, B.G.; Morgan, T.E.; Finch, C.E.; St. Laurent, G., III; Kenny, P.J.; Wahlestedt, C. Expression of a noncoding RNA is elevated in Alzheimer's disease and drives rapid feed-forward regulation of $\beta$-secretase. Nat. Med. 2008, 14, 723-730. [CrossRef]

98. Salmena, L.; Poliseno, L.; Tay, Y.; Kats, L.; Pandolfi, P.P. A ceRNA Hypothesis: The Rosetta Stone of a Hidden RNA Language? Cell 2011, 146, 353-358. [CrossRef]

99. Wang, Y.; Xu, Z.; Jiang, J.; Xu, C.; Kang, J.; Xiao, L.; Wu, M.; Xiong, J.; Guo, X.; Liu, H. Endogenous miRNA Sponge lincRNA-RoR Regulates Oct4, Nanog, and Sox2 in Human Embryonic Stem Cell Self-Renewal. Dev. Cell 2013, 25, 69-80. [CrossRef]

100. Kallen, A.; Zhou, X.-B.; Xu, J.; Qiao, C.; Ma, J.; Yan, L.; Lu, L.; Liu, C.; Yi, J.-S.; Zhang, H.; et al. The Imprinted H19 LncRNA Antagonizes Let-7 MicroRNAs. Mol. Cell 2013, 52, 101-112. [CrossRef] [PubMed]

101. Zhang, X.; Wang, W.; Zhu, W.; Dong, J.; Cheng, Y.; Yin, Z.; Shen, F. Mechanisms and Functions of Long Non-Coding RNAs at Multiple Regulatory Levels. Int. J. Mol. Sci. 2019, 20, 5573. [CrossRef] [PubMed]

102. Li, D.; Liu, X.; Zhou, J.; Hu, J.; Zhang, D.; Liu, J.; Qiao, Y.; Zhan, Q. Long noncoding RNA HULC modulates the phosphorylation of YB-1 through serving as a scaffold of extracellular signal-regulated kinase and YB-1 to enhance hepatocarcinogenesis. Hepatology 2017, 65, 1612-1627. [CrossRef] 
103. Thibaut, F. The role of sex and gender in neuropsychiatric disorders. Dialogues Clin. Neurosci. 2016, 18, 351-352. [CrossRef] [PubMed]

104. Weber, C.M.; Clyne, A.M. Sex differences in the blood-brain barrier and neurodegenerative diseases. APL Bioeng. 2021, 5, 011509. [CrossRef] [PubMed]

105. Rackham, O.; Shearwood, A.-M.J.; Mercer, T.R.; Davies, S.M.; Mattick, J.S.; Filipovska, A. Long noncoding RNAs are generated from the mitochondrial genome and regulated by nuclear-encoded proteins. RNA 2011, 17, 2085-2093. [CrossRef] [PubMed]

106. $\mathrm{Wu}, \mathrm{Y} .-\mathrm{Y} . ; \mathrm{Kuo}, \mathrm{H}$.-C. Functional roles and networks of non-coding RNAs in the pathogenesis of neurodegenerative diseases. J. Biomed. Sci. 2020, 27, 49. [CrossRef] [PubMed]

107. Ma, Q.-L.; Galasko, D.R.; Ringman, J.M.; Vinters, H.V.; Edland, S.D.; Pomakian, J.; Ubeda, O.J.; Rosario, E.R.; Teter, B.; Frautschy, S.A.; et al. Reduction of SorLA/LR11, a Sorting Protein Limiting $\beta$-Amyloid Production, in Alzheimer Disease Cerebrospinal Fluid. Arch. Neurol. 2009, 66, 448-457. [CrossRef]

108. Ciarlo, E.; Massone, S.; Penna, I.; Nizzari, M.; Gigoni, A.; Dieci, G.; Russo, C.; Florio, T.; Cancedda, R.; Pagano, A. An intronic ncRNA-dependent regulation of SORL1 expression affecting A $\beta$ formation is upregulated in post-mortem Alzheimer's disease brain samples. Dis. Model. Mech. 2013, 6, 424-433. [CrossRef]

109. Luo, Q.; Chen, Y. Long noncoding RNAs and Alzheimer's disease. Clin. Interv. Aging 2016, 11, 867-872. [CrossRef]

110. Massone, S.; Vassallo, I.; Fiorino, G.; Castelnuovo, M.; Barbieri, F.; Borghi, R.; Tabaton, M.; Robello, M.; Gatta, E.; Russo, C.; et al. 17A, a novel non-coding RNA, regulates GABA B alternative splicing and signaling in response to inflammatory stimuli and in Alzheimer disease. Neurobiol. Dis. 2011, 41, 308-317. [CrossRef]

111. Gavazzo, P.; Vassalli, M.; Costa, D.; Pagano, A. Novel ncRNAs transcribed by Pol III and elucidation of their functional relevance by biophysical approaches. Front. Cell. Neurosci. 2013, 7, 203. [CrossRef] [PubMed]

112. Buggia-Prévot, V.; Thinakaran, G. Sorting the Role of SORLA in Alzheimer's Disease. Sci. Transl. Med. 2014, 6, 223fs8. [CrossRef]

113. Massone, S.; Ciarlo, E.; Vella, S.; Nizzari, M.; Florio, T.; Russo, C.; Cancedda, R.; Pagano, A. NDM29, a RNA polymerase III-dependent non coding RNA, promotes amyloidogenic processing of APP and amyloid $\beta$ secretion. Biochim. Biophys. Acta 2012, 1823, 1170-1177. [CrossRef] [PubMed]

114. Mus, E.; Hof, P.R.; Tiedge, H. Dendritic BC200 RNA in aging and in Alzheimer's disease. Proc. Natl. Acad. Sci. USA 2007, 104, 10679-10684. [CrossRef]

115. Lin, D.; Pestova, T.V.; Hellen, C.U.T.; Tiedge, H. Translational Control by a Small RNA: Dendritic BC1 RNA Targets the Eukaryotic Initiation Factor 4A Helicase Mechanism. Mol. Cell. Biol. 2008, 28, 3008-3019. [CrossRef] [PubMed]

116. Iacoangeli, A.; Bianchi, R.; Tiedge, H. Regulatory RNAs in brain function and disorders. Brain Res. 2010, 1338, 36-47. [CrossRef]

117. Wang, Z.; Zhao, Y.; Xu, N.; Zhang, S.; Wang, S.; Mao, Y.; Zhu, Y.; Li, B.; Jiang, Y.; Tan, Y.; et al. NEAT1 regulates neuroglial cell mediating $\mathrm{A} \beta$ clearance via the epigenetic regulation of endocytosis-related genes expression. Cell. Mol. Life Sci. 2019, 76, 3005-3018. [CrossRef]

118. Zhao, M.-Y.; Wang, G.-Q.; Wang, N.-N.; Yu, Q.-Y.; Liu, R.-L.; Shi, W.-Q. The long-non-coding RNA NEAT1 is a novel target for Alzheimer's disease progression via miR-124/BACE1 axis. Neurol. Res. 2019, 41, 489-497. [CrossRef] [PubMed]

119. Clemson, C.M.; Hutchinson, J.N.; Sara, S.A.; Ensminger, A.W.; Fox, A.H.; Chess, A.; Lawrence, J.B. An Architectural Role for a Nuclear Noncoding RNA: NEAT1 RNA Is Essential for the Structure of Paraspeckles. Mol. Cell 2009, 33, 717-726. [CrossRef]

120. Suzuki, H.; Shibagaki, Y.; Hattori, S.; Matsuoka, M. C9-ALS/FTD-linked proline-arginine dipeptide repeat protein associates with paraspeckle components and increases paraspeckle formation. Cell Death Dis. 2019, 10, 746. [CrossRef]

121. An, H.; Tan, J.T.; Shelkovnikova, T.A. Stress granules regulate stress-induced paraspeckle assembly. J. Cell Biol. 2019, 218, 4127-4140. [CrossRef]

122. Mizielinska, S.; Grönke, S.; Niccoli, T.; Ridler, C.E.; Clayton, E.L.; Devoy, A.; Moens, T.; Norona, F.E.; Woollacott, I.O.C.; Pietrzyk, J.; et al. C9orf72 repeat expansions cause neurodegeneration in Drosophila through arginine-rich proteins. Science 2014, 345, 1192-1194. [CrossRef] [PubMed]

123. Wen, X.; Tan, W.; Westergard, T.; Krishnamurthy, K.; Markandaiah, S.S.; Shi, Y.; Lin, S.; Shneider, N.; Monaghan, J.; Pandey, U.B.; et al. Antisense Proline-Arginine RAN Dipeptides Linked to C9ORF72-ALS/FTD Form Toxic Nuclear Aggregates that Initiate In Vitro and In Vivo Neuronal Death. Neuron 2014, 84, 1213-1225. [CrossRef] [PubMed]

124. Maharjan, N.; Künzli, C.; Buthey, K.; Saxena, S. C9ORF72 Regulates Stress Granule Formation and Its Deficiency Impairs Stress Granule Assembly, Hypersensitizing Cells to Stress. Mol. Neurobiol. 2016, 54, 3062-3077. [CrossRef] [PubMed]

125. Swinnen, B.; Bento-Abreu, A.; Gendron, T.F.; Boeynaems, S.; Bogaert, E.; Nuyts, R.; Timmers, M.; Scheveneels, W.; Hersmus, N.; Wang, J.; et al. A zebrafish model for C9orf72 ALS reveals RNA toxicity as a pathogenic mechanism. Acta Neuropathol. 2018, 135, 427-443. [CrossRef]

126. Bampton, A.; Gittings, L.; Fratta, P.; Lashley, T.; Gatt, A. The role of hnRNPs in frontotemporal dementia and amyotrophic lateral sclerosis. Acta Neuropathol. 2020, 140, 599-623. [CrossRef]

127. Mizielinska, S.; Lashley, T.; Norona, F.E.; Clayton, E.L.; Ridler, C.E.; Fratta, P.; Isaacs, A.M. C9orf72 frontotemporal lobar degeneration is characterised by frequent neuronal sense and antisense RNA foci. Acta Neuropathol. 2013, 126, 845-857. [CrossRef]

128. Chung, C.-Y.; Berson, A.; Kennerdell, J.R.; Sartoris, A.; Unger, T.; Porta, S.; Kim, H.-J.; Smith, E.R.; Shilatifard, A.; Van Deerlin, V.; et al. Aberrant activation of non-coding RNA targets of transcriptional elongation complexes contributes to TDP-43 toxicity. Nat. Commun. 2018, 9, 4406. [CrossRef] 
129. Li, P.P.; Sun, X.; Xia, G.; Arbez, N.; Paul, S.; Zhu, S.; Peng, H.B.; Ross, C.A.; Koeppen, A.H.; Margolis, R.L.; et al. ATXN2-AS, a gene antisense toATXN2, is associated with spinocerebellar ataxia type 2 and amyotrophic lateral sclerosis. Ann. Neurol. 2016, 80, 600-615. [CrossRef] [PubMed]

130. Gagliardi, S.; Pandini, C.; Garofalo, M.; Bordoni, M.; Pansarasa, O.; Cereda, C. Long non coding RNAs and ALS: Still much to do. Non-Coding RNA Res. 2018, 3, 226-231. [CrossRef] [PubMed]

131. Breijyeh, Z.; Karaman, R. Comprehensive Review on Alzheimer's Disease: Causes and Treatment. Molecules 2020, $25,5789$. [CrossRef]

132. Fan, L.; Mao, C.; Hu, X.; Zhang, S.; Yang, Z.; Hu, Z.; Sun, H.; Fan, Y.; Dong, Y.; Yang, J.; et al. New Insights Into the Pathogenesis of Alzheimer's Disease. Front. Neurol. 2020, 10, 1312. [CrossRef]

133. Maoz, R.; Garfinkel, B.; Soreq, H. Alzheimer's Disease and ncRNAs. Adv. Exp. Med. Biol. 2017, 978, 337-361. [CrossRef] [PubMed]

134. Millan, M.J. Linking deregulation of non-coding RNA to the core pathophysiology of Alzheimer's disease: An integrative review. Prog. Neurobiol. 2017, 156, 1-68. [CrossRef]

135. Cao, M.; Li, H.; Zhao, J.; Cui, J.; Hu, G. Identification of age- and gender-associated long noncoding RNAs in the human brain with Alzheimer's disease. Neurobiol. Aging 2019, 81, 116-126. [CrossRef]

136. Hong, H.; Mo, Y.; Li, D.; Xu, Z.; Liao, Y.; Yin, P.; Liu, X.; Xia, Y.; Fang, J.; Wang, Q.; et al. Aberrant Expression Profiles of lncRNAs and Their Associated Nearby Coding Genes in the Hippocampus of the SAMP8 Mouse Model with AD. Mol. Ther. Nucleic Acids 2020, 20, 140-154. [CrossRef]

137. Wang, D.; Wang, P.; Bian, X.; Xu, S.; Zhou, Q.; Zhang, Y.; Ding, M.; Han, M.; Huang, L.; Bi, J.; et al. Elevated plasma levels of exosomal BACE1-AS combined with the volume and thickness of the right entorhinal cortex may serve as a biomarker for the detection of Alzheimer's disease. Mol. Med. Rep. 2020, 22, 227-238. [CrossRef] [PubMed]

138. Ma, N.; Tie, C.; Yu, B.; Zhang, W.; Wan, J. Identifying lncRNA-miRNA-mRNA networks to investigate Alzheimer's disease pathogenesis and therapy strategy. Aging 2020, 12, 2897-2920. [CrossRef]

139. Yang, B.; Xia, Z.-A.; Zhong, B.; Xiong, X.; Sheng, C.; Wang, Y.; Gong, W.; Cao, Y.; Wang, Z.; Peng, W. Distinct Hippocampal Expression Profiles of Long Non-coding RNAs in an Alzheimer's Disease Model. Mol. Neurobiol. 2017, 54, 4833-4846. [CrossRef] [PubMed]

140. Shafi, O. Inverse relationship between Alzheimer's disease and cancer, and other factors contributing to Alzheimer's disease: A systematic review. BMC Neurol. 2016, 16, 236. [CrossRef]

141. Feng, L.; Liao, Y.-T.; He, J.-C.; Xie, C.-L.; Chen, S.-Y.; Fan, H.-H.; Su, Z.-P.; Wang, Z. Plasma long non-coding RNA BACE1 as a novel biomarker for diagnosis of Alzheimer disease. BMC Neurol. 2018, 18, 4. [CrossRef]

142. Zhou, Y.; Xu, Z.; Yu, Y.; Cao, J.; Qiao, Y.; Qiao, H.; Suo, G. Comprehensive analysis of the lncRNA-associated ceRNA network identifies neuroinflammation biomarkers for Alzheimer's disease. Mol. Omics 2019, 15, 459-469. [CrossRef]

143. Ge, Y.; Song, X.; Liu, J.; Liu, C.; Xu, C. The Combined Therapy of Berberine Treatment with lncRNA BACE1-AS Depletion Attenuates A $325-35$ Induced Neuronal Injury through Regulating the Expression of miR-132-3p in Neuronal Cells. Neurochem. Res. 2020, 45, 741-751. [CrossRef]

144. Li, F.; Wang, Y.; Yang, H.; Xu, Y.; Zhou, X.; Zhang, X.; Xie, Z.; Bi, J. The effect of BACE1-AS on $\beta$-amyloid generation by regulating BACE1 mRNA expression. BMC Mol. Biol. 2019, 20, 23. [CrossRef]

145. Li, H.; Zheng, L.; Jiang, A.; Mo, Y.; Gong, Q. Identification of the biological affection of long noncoding RNA BC200 in Alzheimer's disease. NeuroReport 2018, 29, 1061-1067. [CrossRef]

146. Ahmadi, S.; Zobeiri, M.; Bradburn, S. Molecular mechanisms underlying actions of certain long noncoding RNAs in Alzheimer's disease. Metab. Brain Dis. 2020, 35, 681-693. [CrossRef]

147. Yin, R.-H.; Yu, J.-T.; Tan, L. The Role of SORL1 in Alzheimer's Disease. Mol. Neurobiol. 2014, 51, 909-918. [CrossRef]

148. Holstege, H.; Van Der Lee, S.J.; Hulsman, M.; Wong, T.H.; Van Rooij, J.G.; Weiss, M.M.; Louwersheimer, E.; Wolters, F.J.; Amin, N.; Uitterlinden, A.G.; et al. Characterization of pathogenic SORL1 genetic variants for association with Alzheimer's disease: A clinical interpretation strategy. Eur. J. Hum. Genet. 2017, 25, 973-981. [CrossRef]

149. Guo, C.-C.; Jiao, C.-H.; Gao, Z.-M. Silencing of LncRNA BDNF-AS attenuates A $\beta 25-35$-induced neurotoxicity in PC12 cells by suppressing cell apoptosis and oxidative stress. Neurol. Res. 2018, 40, 795-804. [CrossRef]

150. Bhattacharyya, N.; Pandey, V.; Bhattacharyya, M.; Dey, A. Regulatory role of long non coding RNAs (lncRNAs) in neurological disorders: From novel biomarkers to promising therapeutic strategies. Asian J. Pharm. Sci. 2021, in press. [CrossRef]

151. Douglas, A.G. Non-coding RNA in C9orf72-related amyotrophic lateral sclerosis and frontotemporal dementia: A perfect storm of dysfunction. Non-Coding RNA Res. 2018, 3, 178-187. [CrossRef] [PubMed]

152. Vieira, A.; Dogini, D.; Lopes-Cendes, I. Role of non-coding RNAs in non-aging-related neurological disorders. Braz. J. Med Biol. Res. 2018, 51. [CrossRef] [PubMed]

153. Zarei, S.; Carr, K.; Reiley, L.; Diaz, K.; Guerra, O.; Altamirano, P.F.; Pagani, W.; Lodin, D.; Orozco, G.; Chinea, A. A comprehensive review of amyotrophic lateral sclerosis. Surg. Neurol. Int. 2015, 6, 171. [CrossRef] [PubMed]

154. Masrori, P.; Van Damme, P. Amyotrophic lateral sclerosis: A clinical review. Eur. J. Neurol. 2020, 27, 1918-1929. [CrossRef]

155. Nguyen, T.M.; Kabotyanski, E.B.; Reineke, L.C.; Shao, J.; Xiong, F.; Lee, J.-H.; Dubrulle, J.; Johnson, H.; Stossi, F.; Tsoi, P.S.; et al. The SINEB1 element in the long non-coding RNA Malat1 is necessary for TDP-43 proteostasis. Nucleic Acids Res. 2020, 48, $2621-2642$. [CrossRef] [PubMed] 
156. Wang, C.; Duan, Y.; Duan, G.; Wang, Q.; Zhang, K.; Deng, X.; Qian, B.; Gu, J.; Ma, Z.; Zhang, S.; et al. Stress Induces Dynamic, Cytotoxicity-Antagonizing TDP-43 Nuclear Bodies via Paraspeckle LncRNA NEAT1-Mediated Liquid-Liquid Phase Separation. Mol. Cell 2020, 79, 443-458.e7. [CrossRef] [PubMed]

157. Alberti, S.; Gladfelter, A.; Mittag, T. Considerations and Challenges in Studying Liquid-Liquid Phase Separation and Biomolecular Condensates. Cell 2019, 176, 419-434. [CrossRef]

158. Fernandes, N.; Eshleman, N.; Buchan, J.R. Stress Granules and ALS: A Case of Causation or Correlation? In RNA Metabolism in Neurodegenerative Diseases; Springer: Cham, Switzerland, 2018; pp. 173-212. [CrossRef]

159. Van Treeck, B.; Protter, D.S.W.; Matheny, T.; Khong, A.; Link, C.D.; Parker, R. RNA self-assembly contributes to stress granule formation and defining the stress granule transcriptome. Proc. Natl. Acad. Sci. USA 2018, 115, 2734-2739. [CrossRef]

160. Farg, M.A.; Sundaramoorthy, V.; Sultana, J.M.; Yang, S.; Atkinson, R.A.; Levina, V.; Halloran, M.A.; Gleeson, P.A.; Blair, I.; Soo, K.Y.; et al. C9ORF72, implicated in amytrophic lateral sclerosis and frontotemporal dementia, regulates endosomal trafficking. Hum. Mol. Genet. 2014, 23, 3579-3595. [CrossRef]

161. Webster, C.P.; Smith, E.F.; Bauer, C.S.; Moller, A.; Hautbergue, G.M.; Ferraiuolo, L.; Myszczynska, M.A.; Higginbottom, A.; Walsh, M.J.; Whitworth, A.J.; et al. The C9orf72 protein interacts with Rab1a and the ULK 1 complex to regulate initiation of autophagy. EMBO J. 2016, 35, 1656-1676. [CrossRef] [PubMed]

162. Jain, A.; Vale, A.J.R.D. RNA phase transitions in repeat expansion disorders. Nature 2017, 546, 243-247. [CrossRef] [PubMed]

163. Česnik, A.B.; Darovic, S.; Mihevc, S.P.; Štalekar, M.; Malnar, M.; Motaln, H.; Lee, Y.; Mazej, J.; Pohleven, J.; Grosch, M.; et al. Nuclear RNA foci from C9ORF72 expansion mutation form paraspeckle-like bodies. J. Cell Sci. 2019, 132, jcs224303. [CrossRef]

164. Davidson, Y.S.; Flood, L.; Robinson, A.C.; Nihei, Y.; Mori, K.; Rollinson, S.; Richardson, A.; Benson, B.C.; Jones, M.; Snowden, J.S.; et al. Heterogeneous ribonuclear protein A3 (hnRNP A3) is present in dipeptide repeat protein containing inclusions in Frontotemporal Lobar Degeneration and Motor Neurone disease associated with expansions in C9orf72 gene. Acta Neuropathol. Commun. 2017, 5, 31. [CrossRef]

165. Piccolo, L.L.; Yamaguchi, M. RNAi of arcRNA hsrw affects sub-cellular localization of Drosophila FUS to drive neurodiseases. Exp. Neurol. 2017, 292, 125-134. [CrossRef]

166. Muraoka, Y.; Nakamura, A.; Tanaka, R.; Suda, K.; Azuma, Y.; Kushimura, Y.; Piccolo, L.L.; Yoshida, H.; Mizuta, I.; Tokuda, T.; et al. Genetic screening of the genes interacting with Drosophila FIG4 identified a novel link between CMT-causing gene and long noncoding RNAs. Exp. Neurol. 2018, 310, 1-13. [CrossRef] [PubMed]

167. Ng, S.Y.; Lin, L.; Soh, B.S.; Stanton, L.W. Long noncoding RNAs in development and disease of the central nervous system. Trends Genet. 2013, 29, 461-468. [CrossRef] [PubMed]

168. Shi, C.; Zhang, L.; Qin, C. Long non-coding RNAs in brain development, synaptic biology, and Alzheimer's disease. Brain Res. Bull. 2017, 132, 160-169. [CrossRef]

169. Lipovich, L.; Tarca, A.L.; Cai, J.; Jia, H.; Chugani, H.T.; Sterner, K.N.; Grossman, L.I.; Uddin, M.; Hof, P.R.; Sherwood, C.C.; et al. Developmental Changes in the Transcriptome of Human Cerebral Cortex Tissue: Long Noncoding RNA Transcripts. Cereb. Cortex 2013, 24, 1451-1459. [CrossRef]

170. Wilkinson, B.; Campbell, D.B. Contribution of Long Noncoding RNAs to Autism Spectrum Disorder Risk. Int. Rev. Neurobiol. 2013, 113, 35-59. [CrossRef]

171. Tang, J.; Yu, Y.; Yang, W. Long noncoding RNA and its contribution to autism spectrum disorders. CNS Neurosci. Ther. 2017, 23, 645-656. [CrossRef] [PubMed]

172. Takahashi, S.; Ohtsuki, T.; Yu, S.-Y.; Tanabe, E.-I.; Yara, K.; Kamioka, M.; Matsushima, E.; Matsuura, M.; Ishikawa, K.; Minowa, Y.; et al. Significant linkage to chromosome $22 \mathrm{q}$ for exploratory eye movement dysfunction in schizophrenia. Am. J. Med. Genet. B Neuropsychiatr. Genet. 2003, 123B, 27-32. [CrossRef]

173. Rapicavoli, N.A.; Poth, E.M.; Blackshaw, S. The long noncoding RNA RNCR2 directs mouse retinal cell specification. BMC Dev. Biol. 2010, 10, 49. [CrossRef] [PubMed]

174. Ip, J.Y.; Sone, M.; Nashiki, C.; Pan, Q.; Kitaichi, K.; Yanaka, K.; Abe, T.; Takao, K.; Miyakawa, T.; Blencowe, B.J.; et al. Gomafu IncRNA knockout mice exhibit mild hyperactivity with enhanced responsiveness to the psychostimulant methamphetamine. Sci. Rep. 2016, 6, 27204. [CrossRef] [PubMed]

175. Bernard, D.; Prasanth, K.V.; Tripathi, V.; Colasse, S.; Nakamura, T.; Xuan, Z.; Zhang, M.Q.; Sedel, F.; Jourdren, L.; Coulpier, F.; et al. A long nuclear-retained non-coding RNA regulates synaptogenesis by modulating gene expression. EMBO J. 2010, 29, 3082-3093. [CrossRef]

176. Madabhushi, R.; Gao, F.; Pfenning, A.R.; Pan, L.; Yamakawa, S.; Seo, J.; Rueda, R.; Phan, T.X.; Yamakawa, H.; Pao, P.-C.; et al. Activity-Induced DNA Breaks Govern the Expression of Neuronal Early-Response Genes. Cell 2015, 161, 1592-1605. [CrossRef] [PubMed]

177. Millar, J.K.; James, R.; Brandon, N.; A Thomson, P. DISC1 and DISC2: Discovering and dissecting molecular mechanisms underlying psychiatric illness. Ann. Med. 2004, 36, 367-378. [CrossRef]

178. Chubb, J.E.; Bradshaw, N.J.; Soares, D.C.; Porteous, D.; Millar, J.K. The DISC locus in psychiatric illness. Mol. Psychiatry 2007, 13, 36-64. [CrossRef] [PubMed]

179. Polesskaya, O.O.; Haroutunian, V.; Davis, K.L.; Hernandez, I.; Sokolov, B.P. Novel putative nonprotein-coding RNA gene from 11q14 displays decreased expression in brains of patients with schizophrenia. J. Neurosci. Res. 2003, 74, 111-122. [CrossRef] 
180. Walsh, T.; McClellan, J.M.; McCarthy, S.E.; Addington, A.M.; Pierce, S.B.; Cooper, G.M.; Nord, A.S.; Kusenda, M.; Malhotra, D.; Bhandari, A.; et al. Rare Structural Variants Disrupt Multiple Genes in Neurodevelopmental Pathways in Schizophrenia. Science 2008, 320, 539-543. [CrossRef]

181. Nakagawa, S.; Naganuma, T.; Shioi, G.; Hirose, T. Paraspeckles are subpopulation-specific nuclear bodies that are not essential in mice. J. Cell Biol. 2011, 193, 31-39. [CrossRef]

182. Hirose, T.; Virnicchi, G.; Tanigawa, A.; Naganuma, T.; Li, R.; Kimura, H.; Yokoi, T.; Nakagawa, S.; Bénard, M.; Fox, A.H.; et al. NEAT1 long noncoding RNA regulates transcription via protein sequestration within subnuclear bodies. Mol. Biol. Cell 2014, 25, 169-183. [CrossRef]

183. Wang, Y.; Zhao, X.; Ju, W.; Flory, M.; Zhong, J.; Jiang, S.; Wang, P.; Dong, X.; Tao, X.; Chen, Q.; et al. Genome-wide differential expression of synaptic long noncoding RNAs in autism spectrum disorder. Transl. Psychiatry 2015, 5, e660. [CrossRef]

184. Noor, A.; Whibley, A.; Marshall, C.R.; Gianakopoulos, P.J.; Piton, A.; Carson, A.R.; Orlic-Milacic, M.; Lionel, A.C.; Sato, D.; Pinto, D.; et al. Disruption at the PTCHD1 Locus on Xp22.11 in Autism Spectrum Disorder and Intellectual Disability. Sci. Transl. Med. 2010, 2, 49ra68. [CrossRef]

185. Meng, L.; Person, R.E.; Beaudet, A.L. Ube3a-ATS is an atypical RNA polymerase II transcript that represses the paternal expression of Ube3a. Hum. Mol. Genet. 2012, 21, 3001-3012. [CrossRef]

186. Meng, L.; Person, R.E.; Huang, W.; Zhu, P.J.; Costa-Mattioli, M.; Beaudet, A.L. Truncation of Ube3a-ATS Unsilences Paternal Ube3a and Ameliorates Behavioral Defects in the Angelman Syndrome Mouse Model. PLoS Genet. 2013, 9, e1004039. [CrossRef] [PubMed]

187. Meng, L.; Ward, A.J.; Chun, S.; Bennett, C.F.; Beaudet, A.L.; Rigo, F. Towards a therapy for Angelman syndrome by targeting a long non-coding RNA. Nature 2015, 518, 409-412. [CrossRef]

188. Hosseini, E.; Bagheri-Hosseinabadi, Z.; De Toma, I.; Jafarisani, M.; Sadeghi, I. The importance of long non-coding RNAs in neuropsychiatric disorders. Mol. Asp. Med. 2019, 70, 127-140. [CrossRef]

189. Wang, Y.; Fang, Y.; Zhang, F.; Xu, M.; Zhang, J.; Yan, J.; Ju, W.; Brown, W.T.; Zhong, N. Hypermethylation of the enolase gene (ENO2) in autism. Eur. J. Pediatr. 2014, 173, 1233-1244. [CrossRef] [PubMed]

190. Wegiel, J.; Kuchna, I.; Nowicki, K.; Imaki, H.; Wegiel, J.; Marchi, E.; Ma, S.Y.; Chauhan, A.; Chauhan, V.; Bobrowicz, T.W.; et al. The neuropathology of autism: Defects of neurogenesis and neuronal migration, and dysplastic changes. Acta Neuropathol. 2010, 119, 755-770. [CrossRef]

191. Lin, M.; Pedrosa, E.; Shah, A.; Hrabovsky, A.; Maqbool, S.; Zheng, D.; Lachman, H.M. RNA-Seq of Human Neurons Derived from iPS Cells Reveals Candidate Long Non-Coding RNAs Involved in Neurogenesis and Neuropsychiatric Disorders. PLoS ONE 2011, 6, e23356. [CrossRef] [PubMed]

192. Rusconi, F.; Battaglioli, E.; Venturin, M. Psychiatric Disorders and lncRNAs: A Synaptic Match. Int. J. Mol. Sci. 2020, 21, 3030. [CrossRef] [PubMed]

193. Smith, S.E.P.; Zhou, Y.-D.; Zhang, G.; Jin, Z.; Stoppel, D.C.; Anderson, M.P. Increased Gene Dosage of Ube3a Results in Autism Traits and Decreased Glutamate Synaptic Transmission in Mice. Sci. Transl. Med. 2011, 3, 103ra97. [CrossRef]

194. Vatsa, N.; Jana, N.R. UBE3A and Its Link with Autism. Front. Mol. Neurosci. 2018, 11, 448. [CrossRef] [PubMed]

195. Khatri, N.; Man, H.Y. The Autism and Angelman Syndrome Protein Ube3A/E6AP: The Gene, E3 Ligase Ubiquitination Targets and Neurobiological Functions. Front. Mol. Neurosci. 2019, 12, 109. [CrossRef]

196. Velmeshev, D.; Magistri, M.; Faghihi, M. Expression of non-protein-coding antisense RNAs in genomic regions related to autism spectrum disorders. Mol. Autism 2013, 4, 32. [CrossRef]

197. Kerin, T.; Ramanathan, A.; Rivas, K.; Grepo, N.; Coetzee, G.A.; Campbell, D.B. A Noncoding RNA Antisense to Moesin at 5p14.1 in Autism. Sci. Transl. Med. 2012, 4, 128ra40. [CrossRef] [PubMed]

198. DeWitt, J.J.; Grepo, N.; Wilkinson, B.; Evgrafov, O.V.; Knowles, J.A.; Campbell, D.B. Impact of the Autism-Associated Long Noncoding RNA MSNP1AS on Neuronal Architecture and Gene Expression in Human Neural Progenitor Cells. Genes 2016, 7, 76. [CrossRef]

199. Luo, T.; Ou, J.N.; Cao, L.F.; Peng, X.Q.; Li, Y.M.; Tian, Y.Q. The Autism-Related lncRNA MSNP1AS Regulates Moesin Protein to Influence the RhoA, Rac1, and PI3K/Akt Pathways and Regulate the Structure and Survival of Neurons. Autism Res. 2020, 13, 2073-2082. [CrossRef]

200. Luo, T.; Liu, P.; Wang, X.Y.; Li, L.Z.; Zhao, L.P.; Huang, J.; Li, Y.M.; Ou, J.L.; Peng, X.Q. Effect of the autism-associated lncRNA Shank2-AS on architecture and growth of neurons. J. Cell. Biochem. 2018, 120, 1754-1762. [CrossRef]

201. Zaslavsky, K.; Zhang, W.B.; McCready, F.P.; Rodrigues, D.C.; Deneault, E.; Loo, C.; Zhao, M.; Ross, P.J.; Hajjar, J.E.; Romm, A.; et al. SHANK2 mutations associated with autism spectrum disorder cause hyperconnectivity of human neurons. Nat. Neurosci. 2019, 22, 556-564. [CrossRef] [PubMed]

202. Ghafouri-Fard, S.; Namvar, A.; Arsang-Jang, S.; Komaki, A.; Taheri, M. Expression Analysis of BDNF, BACE1, and Their Natural Occurring Antisenses in Autistic Patients. J. Mol. Neurosci. 2020, 70, 194-200. [CrossRef]

203. Khavari, B.; Cairns, M.J. Epigenomic Dysregulation in Schizophrenia: In Search of Disease Etiology and Biomarkers. Cells 2020, 9, 1837. [CrossRef] [PubMed] 
204. Wang, Y.; Wang, X.; Ma, Y.; Wang, Y.X.; Di, Y. Expression profiles of long noncoding RNAs in retinopathy of prematurity. Neural Regen. Res. 2020, 15, 1962-1968. [CrossRef] [PubMed]

205. Barry, G.; Briggs, J.; Vanichkina, D.; Poth, E.; Beveridge, N.; Ratnu, V.; Nayler, S.; Nones, K.; Hu, J.; Bredy, T.; et al. The long non-coding RNA Gomafu is acutely regulated in response to neuronal activation and involved in schizophrenia-associated alternative splicing. Mol. Psychiatry 2014, 19, 486-494. [CrossRef] [PubMed]

206. Safa, A.; Badrlou, E.; Arsang-Jang, S.; Sayad, A.; Taheri, M.; Ghafouri-Fard, S. Expression of NF- $k B$ associated lncRNAs in schizophrenia. Sci. Rep. 2020, 10, 18105. [CrossRef] [PubMed] 